University of Louisville

ThinkIR: The University of Louisville's Institutional Repository

$12-2012$

\title{
The effect of implant placement and simultaneous soft tissue augmentation in the esthetic zone using either connective tissue autograft or acellular dermal matrix allograft on peri-implant hard and soft tissue healing.
}

Gretchen A. Wigand

University of Louisville

Follow this and additional works at: https://ir.library.louisville.edu/etd

\section{Recommended Citation}

Wigand, Gretchen A., "The effect of implant placement and simultaneous soft tissue augmentation in the esthetic zone using either connective tissue autograft or acellular dermal matrix allograft on peri-implant hard and soft tissue healing." (2012). Electronic Theses and Dissertations. Paper 1567.

https://doi.org/10.18297/etd/1567

This Master's Thesis is brought to you for free and open access by ThinkIR: The University of Louisville's Institutional Repository. It has been accepted for inclusion in Electronic Theses and Dissertations by an authorized administrator of ThinkIR: The University of Louisville's Institutional Repository. This title appears here courtesy of the author, who has retained all other copyrights. For more information, please contact thinkir@louisville.edu. 


\title{
THE EFFECT OF IMPLANT PLACEMENT AND SIMULTANEOUS SOFT TISSUE AUGMENTATION IN THE ESTHETIC ZONE USING EITHER CONNECTIVE TISSUE AUTOGRAFT OR ACELLULAR DERMAL MATRIX ALLOGRAFT ON PERI-IMPLANT HARD AND SOFT TISSUE HEALING
}

\author{
By \\ Gretchen A. Wigand \\ D.M.D., University of Louisville School of Dentistry, 2009
}

\author{
A Thesis \\ Submitted to the Faculty of the \\ School of Dentistry of the University of Louisville \\ in Partial Fulfillment of the Requirements \\ for the Degree of
}

Master of Science

Program in Oral Biology

School of Dentistry

University of Louisville

Louisville, Kentucky

December 2012 


\title{
THE EFFECT OF IMPLANT PLACEMENT AND SIMULTANEOUS SOFT TISSUE AUGMENTATION IN THE ESTHETIC ZONE USING EITHER CONNECTIVE TISSUE AUTOGRAFT OR ACELLULAR DERMAL MATRIX ALLOGRAFT ON PERI-IMPLANT HARD AND SOFT TISSUE HEALING
}

\author{
By \\ Gretchen A. Wigand \\ D.M.D., University of Louisville School of Dentistry, 2009
}

A Thesis Approved on

December 3, 2012

By the following Thesis Committee:

Henry Greenwell, Thesis Director

Margaret Hill

R. Vidal

Dean Morton 


\section{DEDICATION}

This thesis is dedicated to my husband, Jeff, who has been my rock and greatest cheerleader. I would not have made it through the past three years without his continuous support and encouragement. I would also like to thank my co-residents, Dr. Peterson and Dr. Poulias, who made the past few years so memorable. 


\section{ACKNOWLEDGEMENTS}

I would like to express my sincere gratitude to the following individuals:

Dr. Henry Greenwell, Program Director of Graduate Periodontics, for your endless encouragement, support and mentoring throughout my periodontics training. Your commitment and dedication in the preparation of this thesis and throughout my residency is truly appreciated. I am forever grateful to you for never letting me give up this amazing opportunity.

Dr. Margaret Hill, Assistant Program Director, for your guidance and support throughout these past few years. Your compassion and willingness to listen is truly appreciated. It has been a pleasure working with you. 


\begin{abstract}
THE EFFECT OF IMPLANT PLACEMENT AND SIMULTANEOUS SOFT TISSUE AUGMENTATION IN THE ESTHETIC ZONE USING EITHER CONNECTIVE TISSUE AUTOGRAFT OR ACELLULAR DERMAL MATRIX ALLOGRAFT ON PERI-IMPLANT HARD AND SOFT TISSUE HEALING Gretchen A. Wigand, DMD
\end{abstract}

December 3, 2012

Aims. The primary aims of this randomized, controlled, blinded clinical trial were to compare the hard and soft tissue response following either a connective tissue (CT) or acellular dermal matrix (ADM) graft placed simultaneously with a laser-grooved implant. Methods. Twenty-five patients received a single tooth implant in the maxillary anterior that was bordered by two teeth. Patients were randomly selected, using to coin toss, to receive either an ADM (test) or a CT (control) graft. At the 2-month appointment, the implant was uncovered and a lab-fabricated provisional was placed. At the 4 -month appointment, following 2 months of tissue shaping, a fixture level impression was obtained to capture the emergence profile. The final restoration was constructed and placed. Subjective and objective evaluations of the implant esthetics were obtained at the 6-month follow-up. 


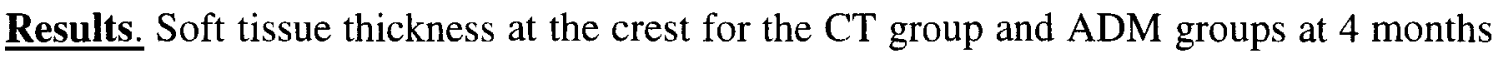
was $2.8 \mathrm{~mm}$ and $2.9 \mathrm{~mm}$ respectively. ADM showed a greater increase in thickness than $\mathrm{CT}$, but the gain was not statistically significant. Facial recession at 6 months for the CT group was $0.3 \pm 0.4 \mathrm{~mm}$ and $\mathrm{ADM}$ group was $0.5 \pm 0.5 \mathrm{~mm}(\mathrm{p}>0.05)$. Gingival margin harmony was $64 \%$ (9 of 14) for the CT group and $45 \%$ (5 of 11) for the ADM group. Papilla harmony was achieved in $36 \%$ (5 of 14) of cases in the CT group and $27 \%$ ( 3 of 11) for the ADM group. Using the Jemt papilla index, the ADM group had $\geq 50 \%$ papilla fill in $100 \%$ of sites (22 of 22) while the CT group had $93 \%$ (26 of 28 ) of sites. Implant platform to osseous crest, at 6 months, for the CT group was $-0.4 \pm 0.4 \mathrm{~mm}$ for the mesial and $-0.2 \pm 0.3 \mathrm{~mm}$ for the distal $(\mathrm{p}<0.05)$. The ADM group was $-0.3 \pm 0.5 \mathrm{~mm}$ for the mesial $(\mathrm{p}<0.05)$ and $-0.2 \pm 0.4 \mathrm{~mm}$ for the distal. The Pink Esthetic Score was $11.6 \pm$ 1.5 for the CT group and $11.7 \pm 1.6$ for the ADM group. The White Esthetic score was $8.2 \pm 1.3 \mathrm{~mm}$ for the CT group and $8.7 \pm 1.5 \mathrm{~mm}$ for the ADM group. Patient's subjective esthetic scores showed patients were equally satisfied with both treatment groups.

Conclusions. Facial recession and gingival margin harmony were similar for both treatment groups. Jemt papilla index scores and papilla harmony were similar for both groups. Loss of osseous crest on the mesial and distal of the implants was similar in both treatment groups and was greatest between times 2 to 6 months. Subjective patient assessment of esthetics using the Visual Analog Scale was similar for CT and ADM groups. 
TABLE OF CONTENTS

PAGE

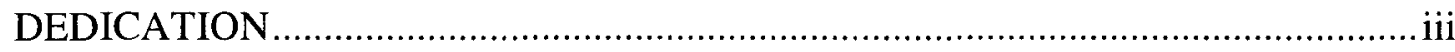

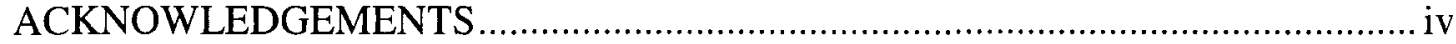

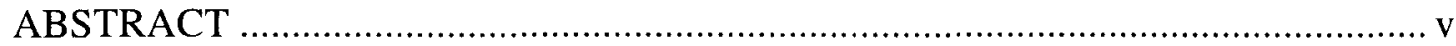

TABLE OF CONTENTS ………........................................................................

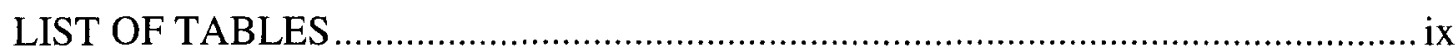

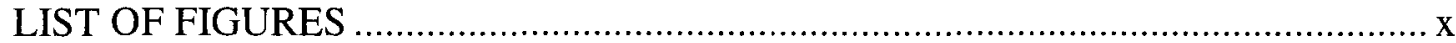

\section{CHAPTER}

\section{LITERATURE REVIEW}

Criteria for Implant Success .................................................................... 2

Success of Delayed Implant Placement .............................................. 5

Soft Tissue Stability Around Implants .................................................. 7

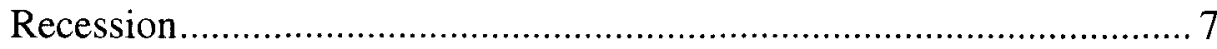

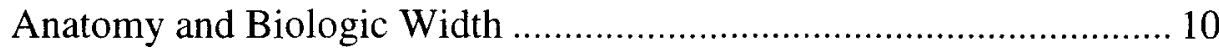

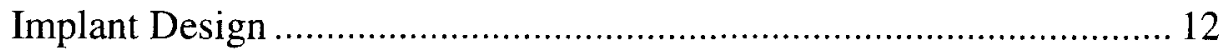

Rationale for the Laser-Lok Collar Design ......................................... 12

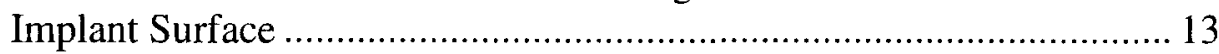

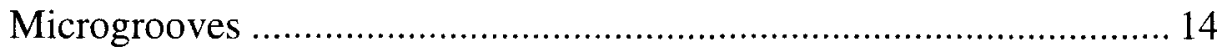

Abutment Design ................................................... 15

Rational for the Laser Microgrooved Abutments.....................15

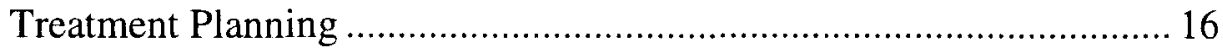

Presence of Papilla ……….................................................................... 16

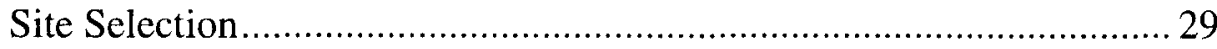

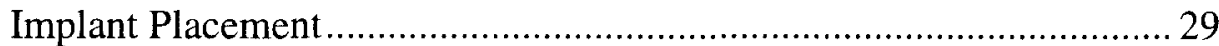

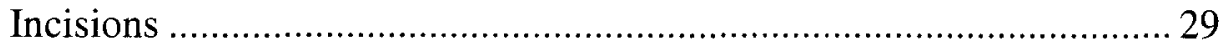

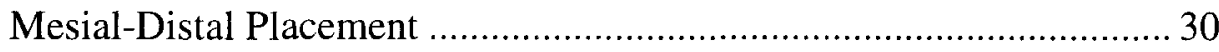

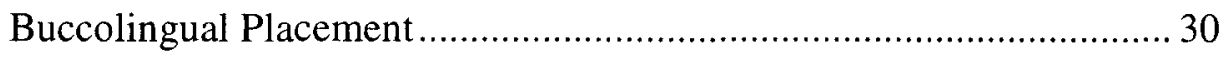

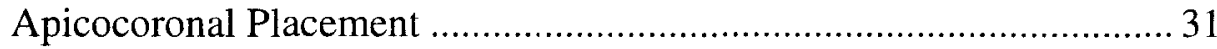

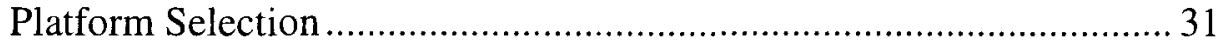

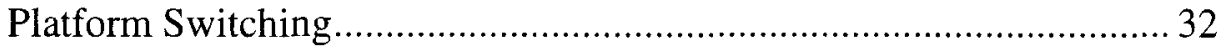

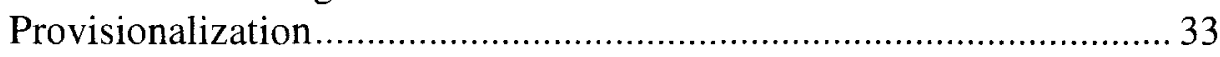




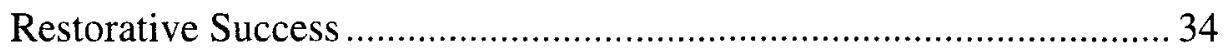

Soft Tissue Augmentation .................................................................. 35

\section{MATERIALS AND METHODS}

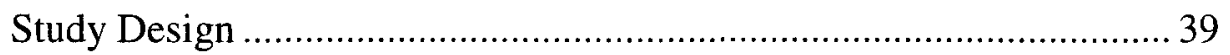

Inclusion Criteria............................................................................ 40

Exclusion Criteria

Post-Surgical Exclusion ...................................................................... 41

Pre-surgical Management................................................................... 41

Clinical Indices at the Tooth-Implant Site ........................................... 41

Pre-surgical Measurements at the Tooth-Implant Site ............................ 42

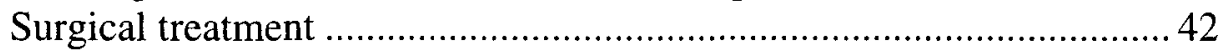

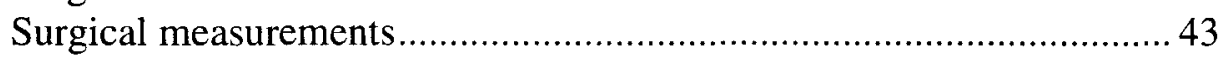

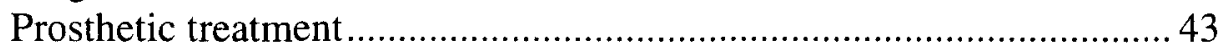

Measurements for the implant at 2, 4, and 6 months ............................ 45

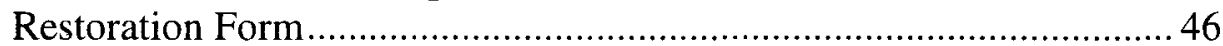

Measurement Techniques................................................................. 46

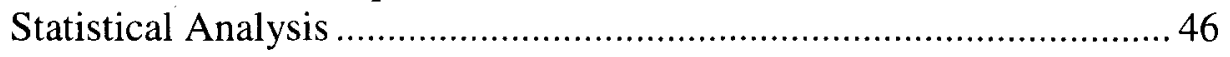

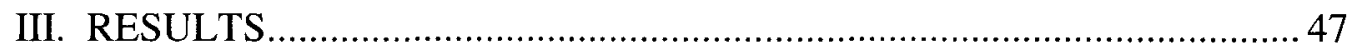

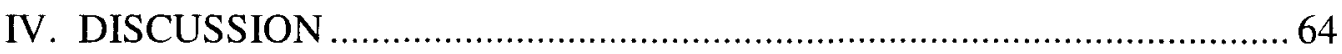

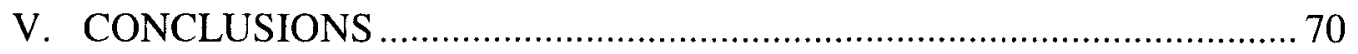

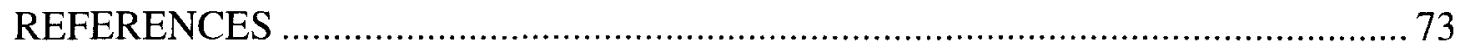

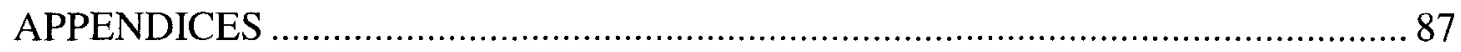

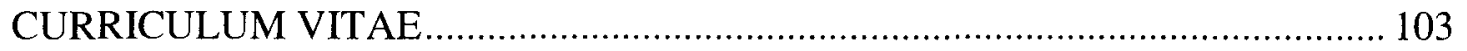




\section{LIST OF TABLES}

PAGE

1. Success of Delayed Implants ............................................................................. 5

2. Success of Maxillary Single/Multi-tooth Replacement ............................................ 6

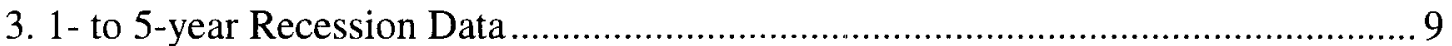

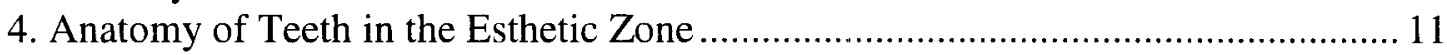

5. Papilla Fill from Crown Insertion to 5 years ...................................................... 18

6. Horizontal and Vertical Bone to Contact Distance for Predictable Papilla.............. 22

7. Papilla Height Relative to Periodontal Biotype ………………….......................... 22

8. Tooth-Implant Papilla Fill Relative to Osseous Crest to Contact Distance.............. 24

9. Papilla Fill Relative to the Tooth-Implant Horizontal Distance ................................ 25

10. Implant-Implant Papilla Fill Relative to Osseous Crest to Contact Distance......... 27

11. Implant-Implant Papilla Fill Relative to Horizontal Inter-implant Distance.......... 27

12. London's Optimal Implant Diameters ........................................................... 32

13. Implant Placement Data............................................................................ 54

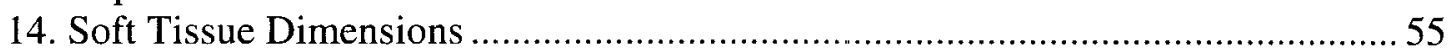

15. Dimensions Related to Papilla Formation …………….....................................56

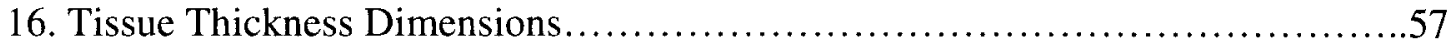

17. Frequency of Papilla and Gingival Margin Harmony ……….............................5 58

18. Objective and Subjective Evaluation of Implant Esthetics....................................59

19. Jemt Papilla Index Stratified by Amount of Vertical Fill ........................................ 60

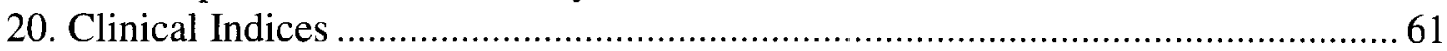

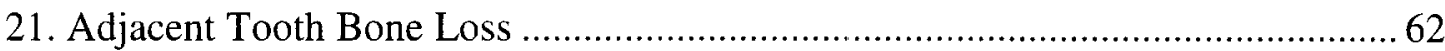

22. Radiographic Implant Platform to Interproximal Osseous Crest ...........................63 


\section{LIST OF FIGURES}

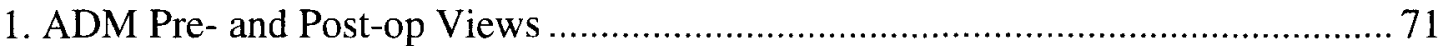

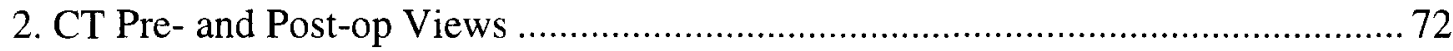




\section{CHAPTER I}

\section{LITERATURE REVIEW}

The loss of a single tooth in the esthetic zone in a patient with an otherwise healthy periodontium can be a distressing experience. Today implant placement after the extraction of a single tooth is a common practice. The clinician can chose from various treatment options, such as immediate, early or delayed implant placement. Initially osseointegration and improved function were the main objectives of implant therapy. Grutter and Belser (2009) conducted a comprehensive search pertaining to immediate restored or conventional loaded implants in the esthetic zone. Analysis of 1,922 implants revealed a 1-year survival rate of $97.3 \%$, and a 1-5 year survival rate of $96 \%$. However, a shift towards achieving highly aesthetic outcomes has become the focus of both patients and clinicians. Achieving harmonious gingival esthetics with an implant restoration makes implant therapy in the anterior esthetic region a challenging procedure. A major esthetic concern is peri-implant soft tissue recession, which can occur both facially and interproximally. Gingival recession is the most common complication of single tooth implants (Goodacre et al. 1999). Multiple factors contribute the esthetic success of a single tooth implants: implant position and inclination, gingival biotype, gingival contour, facial bone thickness and height, osseous scallop, interproximal bone level, and restoration form and emergence. In order to achieve an esthetic outcome, emphasis has 
been placed on the relationship of these parameters to peri-implant gingival esthetics.

\section{Criteria for Implant Success}

Albrektsson et al. (1986) developed the following criteria that have become the standard by which implant success is determined:

1. That an individual, unattached implant is immobile when tested clinically.

2. That a radiograph does not demonstrate any evidence of peri-implant radiolucency.

3. That vertical bone loss is less than $0.2 \mathrm{~mm}$ annually following the first year of service.

4. That individual implant performance is characterized by an absence of persistent and/or irreversible signs and symptoms such as pain, infection, neuropathies, paresthesias, or violation of the mandibular canal.

5. That, in the context of the above, a successful rate of $85 \%$ at the end of a 5 -year observation period and $80 \%$ at the end of a 10 -year period is a minimum criterion for success.

This was modified by Roos et al. (1997) to include different grades of success for implants. The new classification is as follows:

Grade 1:

1. Absence of mobility is checked by individual testing of the unattached implant, using a light tightening force of an abutment screwdriver without simultaneous counteracting of the force via an abutment clamp. 
Any mobility or sensation/pain from the anchorage unit is regarded as a sign of lost osseointegration.

2. Radiographic evaluation of each implant reveals not more than $1.0 \mathrm{~mm}$ of marginal bone loss during the first year of loading, followed by not more than $0.2 \mathrm{~mm}$ resorption per year, as well as absence of periimplant pathosis, such as a peri-implant radiolucency.

3. Severe soft tissue infections, persistent pain, paresthesia, discomfort, etc, are absent.

Grade 2:

1. Radiographic evaluation of each implant reveals not more than $1.0 \mathrm{~mm}$ of marginal bone loss during the first year of loading, followed by not more than $0.2 \mathrm{~mm}$ resorption per year, as well as absence of periimplant pathosis, such as a peri-implant radiolucency.

2. Severe soft tissue infections, persistent pain, paresthesia, discomfort, etc, are absent.

Grade 3:

1. Radiographic evaluation of each implant reveals not more than $0.2 \mathrm{~mm}$ of marginal bone resorption during the last year, but previously more than $1.0 \mathrm{~mm}$ of bone loss has taken place. Peri-implant pathosis, such as a peri-implant radiolucency is absent.

2. Severe soft tissue infections, persistent pain, paresthesia, discomfort, etc, are absent.

Smith and Zarb (1989) proposed the following criteria for implant success: 
1. The individual unattached implant is immobile when tested clinically.

2. No evidence of peri-implant radiolucency is present as assessed on an undistorted radiograph.

3. The mean vertical bone loss is less than $0.2 \mathrm{~mm}$ annually after the first year of service.

4. No persistent pain, discomfort, or infection is attributable to the implant.

5. The implant design does not preclude placement of a crown or prosthesis with an appearance that is satisfactory to the patient and dentist.

6. By these criteria, a success rate of $85 \%$ at the end of a 5-year observation period and $80 \%$ at the end of a 10 -year period are minimum levels for success.

Buser et al. (1990) proposed the following criteria for implant success:

1. Absence of persistent subjective complaints, such as pain, foreign body sensation and/or dysaesthesia.

2. Absence of a recurrent peri-implant infection with suppuration

3. Absence of mobility

4. Absence of a continuous radiolucency around the implant

5. Possibility for restoration.

\section{Success of Delayed Implant Placement}

Studies have demonstrated that implant therapy is predictable and successful. Table 1 shows implant success rates to be approximately $93 \%$ and survival $96 \%$. 
Table 1

Success of Delayed Implants

\begin{tabular}{|c|c|c|c|c|c|c|c|c|c|}
\hline Author & $\begin{array}{l}\text { Term } \\
\text { (yrs) }\end{array}$ & $\begin{array}{c}\text { Mean } \\
\text { (yrs) }\end{array}$ & Implant & Pts & $\underset{\text { impl }}{\mathbf{N}}$ & $\begin{array}{c}\text { Success } \\
\%\end{array}$ & Max. & Mand. & $\begin{array}{c}\text { Survival } \\
\%\end{array}$ \\
\hline Wheeler 1996 & 8.0 & 8.0 & TPS & 479 & 891 & & 80.6 & 96.2 & 92.7 \\
\hline Wheeler 1996 & 8.0 & 8.0 & $\mathrm{HA}$ & & 313 & & 74.1 & 80.5 & 77.8 \\
\hline $\begin{array}{l}\text { Buser et al. } \\
1997\end{array}$ & 8.0 & 8.0 & ITI & 1003 & 2359 & 93.3 & 87.3 & 94.8 & 96.7 \\
\hline $\begin{array}{l}\text { Rosenberg et } \\
\text { al. } 1998\end{array}$ & 7.5 & 7.0 & Multiple & 322 & 958 & 93.00 & & & \\
\hline $\begin{array}{l}\text { Wyatt and } \\
\text { Zarb } 1998\end{array}$ & $\begin{array}{c}1 \text { to } \\
12\end{array}$ & 5.0 & Branemark & 77 & 230 & 94.00 & & & \\
\hline $\begin{array}{l}\text { Grunder et al. } \\
1999\end{array}$ & 3.0 & 3.0 & Multiple & 143 & 264 & 93.30 & 92.40 & 94.70 & \\
\hline $\begin{array}{l}\text { Morris and } \\
\text { Ochi } 2000\end{array}$ & 3 to 5 & 4.0 & Spectra & 829 & 2998 & & & & 92.1 \\
\hline $\begin{array}{l}\text { van } \\
\text { Steenberghe } \\
\text { et al. } 2000\end{array}$ & 2.0 & 2.0 & Multiple & 18 & 95 & 98.9 & & & \\
\hline $\begin{array}{l}\text { Zitzmann et } \\
\text { al. } 2001\end{array}$ & 5.0 & 5.0 & Branemark & 75 & 153 & & & & 95.8 \\
\hline $\begin{array}{l}\text { Davarpanah } \\
\text { et al. } 2002\end{array}$ & 1 to 5 & 3.0 & $3 \mathrm{i}$ & 528 & 1583 & 96.50 & 97.20 & 95.80 & \\
\hline $\begin{array}{l}\text { Naert et al. } \\
2002\end{array}$ & 16.0 & 16.0 & Branemark & 660 & 1956 & 91.40 & & & \\
\hline $\begin{array}{l}\text { Aalam and } \\
\text { Nowzari } 2005\end{array}$ & 2.0 & 2.0 & Multiple & 74 & 198 & 100 & 100 & 100 & \\
\hline $\begin{array}{l}\text { Degidi et al. } \\
2006\end{array}$ & 1.0 & 1.0 & Friadent & 321 & 802 & 91.4 & 91.2 & 91.6 & 99.6 \\
\hline $\begin{array}{l}\text { Khayat and } \\
\text { Milliez } 2007\end{array}$ & 2.0 & 2.0 & Zimmer & 328 & 835 & 98.6 & 98.6 & 98.8 & 99.4 \\
\hline $\begin{array}{l}\text { Raes et al. } \\
2011\end{array}$ & 1.0 & 1.0 & Astra & 23 & 23 & & 100 & & 100 \\
\hline $\begin{array}{l}\text { deBruyn et al. } \\
2011\end{array}$ & 3.0 & 3.0 & Nobel & 49 & 53 & 80 & & & 100 \\
\hline $\begin{array}{l}\text { Patel et al. } \\
2012\end{array}$ & 1.0 & 1.0 & $\begin{array}{c}\text { Straumann } \\
\text { TL }\end{array}$ & 27 & 27 & 84 & & & 100 \\
\hline $\begin{array}{l}\text { Penarrocha- } \\
\text { Oltra et al. } \\
2012\end{array}$ & 1.0 & 1.0 & Impladent & & 88 & 93 & 93 & & 96 \\
\hline Mean & & 4.4 & & 310 & 768 & 93 & 91 & 94 & 96 \\
\hline
\end{tabular}

Maxillary anterior tooth replacements have a success and survival rates of approximately 96 and $98 \%$ respectively (Table 2). 
Table 2

\section{Success of Maxillary Anterior Single/Multi-tooth Replacement}

\begin{tabular}{|c|c|c|c|c|c|c|}
\hline Author & $\begin{array}{l}\text { Term } \\
\text { (yrs) }\end{array}$ & $\begin{array}{c}\text { Mean } \\
\text { (yrs) }\end{array}$ & Implant & $\underset{\text { impl }}{\mathbf{N}}$ & Success & Survival \\
\hline Jemt et al. 1991 & 1.0 & 1.0 & Branemark & 107 & & 97.2 \\
\hline Andersson et al. 1993 & 2 to 4 & 3 & Branemark & 102 & & 98.0 \\
\hline Jemt and Petterson 1993 & 3.0 & 3.0 & Branemark & 70 & & 98.6 \\
\hline Schmitt and Zarb 1993 & 1.4 to 6.6 & 4.0 & Branemark & 27 & 100.0 & \\
\hline Ekfeldt et al. 1994 & 1 to 3 & 2.0 & Branemark & 93 & & 97.8 \\
\hline Laney et al. 1994 & 3.0 & 3.0 & Branemark & 95 & & 97.2 \\
\hline Andersson et al. 1995 & 3 year & 3.0 & Branemark & 65 & & 97.3 \\
\hline Engquist et al. 1995 & 1 to 5 & 3.0 & Branemark & 82 & & 97.6 \\
\hline $\begin{array}{l}\text { Avivi-Arber and Zarb } \\
1996\end{array}$ & 1 to 8 & 4.0 & Branemark & 49 & 84 & 98 \\
\hline Henry et al. 1996 & 5.0 & 5.0 & Branemark & 71 & 96.6 & \\
\hline Melevez et al. 1996 & 5 & 5.0 & Branemark & 84 & & 97.7 \\
\hline Walther et al. 1996 & 10.0 & 10.0 & Branemark & 236 & 89.0 & \\
\hline Karlsson et al. 1997 & 2 & 2.0 & Astra & 47 & & 100 \\
\hline Kemppainen et al. 1997 & 1.0 & 1.0 & Astra & 46 & 97.8 & \\
\hline Kemppainen et al. 1997 & 1.0 & 1.0 & ITI & 56 & 100.0 & \\
\hline Levine et al. 1997 & 6 month & 0.5 & ITI & 174 & 97.7 & 100 \\
\hline Norton 1997 & 6 & 6.0 & Astra & 27 & & 100 \\
\hline Palmer et al. 1997 & 2 & 2.0 & Astra & 15 & & 100 \\
\hline Scheller et al. 1998 & 1 to 5 & 3.0 & Branemark & 99 & 95.9 & 98 \\
\hline Levine et al. 1999 & 2 & 2.0 & ITI & 174 & & 95.5 \\
\hline Moberg et al. 1999 & 3 to 4 & 3.0 & ITI & 30 & & 96.7 \\
\hline Priest 1999 & 10 & 10.0 & Branemark & 116 & & 97.4 \\
\hline Scholander 1999 & 1 to 9 & 5.0 & Branemark & 259 & 98.3 & 98.5 \\
\hline Thilander et al. 1999 & 8 & 8.0 & Branemark & 15 & & 100 \\
\hline Palmer et al. 2000 & 5.0 & 5.0 & Astra & 15 & 100.0 & \\
\hline Haas et al. 2002 & 10.0 & 10.0 & Branemark & 76 & & 93 \\
\hline Romeo et al. 2002 & 7.0 & 7.0 & ITI & 187 & 96.2 & 99.35 \\
\hline Palmer et al. 2003 & 2.5 & 2.0 & Astra & 15 & 100.0 & \\
\hline Levin et al., 2005 & 1 to 9 & 5.0 & Multiple & 52 & 92.6 & \\
\hline Schropp et al. 2005 & 2.0 & 2.0 & $3 i$ & 46 & 93.5 & \\
\hline Buser et al. 2008 & 2 to 5 & 3.0 & Straumann & 45 & 100.0 & \\
\hline Schropp et al. 2008 & 5.0 & 5.0 & $3 i$ & 22 & & 95 \\
\hline Ribeiro et al. 2008 & 1.5 to 3.3 & 2.0 & Multiple & 36 & 100 & \\
\hline Cooper et al. 2008 & 3 & 3.0 & Astra & 54 & & 94 \\
\hline Belser et al. 2009 & $2-4$ & & Straumann & 45 & 100 & 100 \\
\hline Valentini et al. 2010 & 1 & 1.0 & Astra & 43 & & 95 \\
\hline Cosyn et al. 2011 & 3 & 3.0 & Nobel Repl & 25 & & 96 \\
\hline Kan et al. 2011 & 4 & 4.0 & Nobel Repl & 35 & 100.0 & 96 \\
\hline Koh et al. 2011 & 4 & 0.3 & Laser Lok & 24 & & \\
\hline Raes et al. 2011 & 1 & 1.0 & Astra & 16 & & 94.0 \\
\hline Raes et al. 2011 & 1 & 1.0 & Astra & 23 & & 100 \\
\hline Buser et al. 2011 & 3 & 3.0 & Straumann & 20 & 100.0 & 100 \\
\hline Chung et al. 2011 & 1 & 1.0 & $3 \mathrm{i}$ Osseotite & 10 & 90.0 & \\
\hline Lops et al. 2011 & 1 & 1.0 & Astra & 25 & & 100 \\
\hline Lops et al. 2011 & 1 & 1.0 & Straumann & 25 & & 100 \\
\hline Mean & & 3.5 & & 67.7 & 96.3 & 97.7 \\
\hline
\end{tabular}




\section{Soft Tissue Stability Around Implants}

Recession. Goodacre et al. (2003) studied complications associated with dental implants and found that gingival recession was the most common complication (16\%). A number of factors appear to influence the level of soft tissue around dental implants. These factors include: peri-implant biotype, facial, interproximal and crestal bone bone levels, implant fixture level, and implant position and inclination. Jemt et al. (2006) reported $1.0 \mathrm{~mm}$ or greater of facial recession in $17-40 \%$ of the study subjects. In a study conducted by Evans and Chen (2008) a mean facial recession of $0.5-1.0 \mathrm{~mm}$ was reported around single-tooth implants.

The amount of recession is different in patients that have either thick or thin tissue or narrow or wide keratinized tissue. In study conducted by Zigdon et al. (2008) evaluating 63 implants in 32 patients, it was concluded that a wider mucosal band (>1 $\mathrm{mm}$ ) was associated with less marginal recession compared to a narrow (less than equal to $1 \mathrm{~mm}$ ) band $(0.27$ and $0.29 \mathrm{~mm}, \mathrm{p}=0.001)$. A thick mucosa (greater than or equal to 1 $\mathrm{mm})$ was associated with less recession compared with a thin $(<1 \mathrm{~mm})$ mucosa $(0.45$ and $0.9 \mathrm{~mm}, \mathrm{p}=0.04)$. Kan et al. 2011, showed that sites with thick gingival biotypes exhibited significantly smaller changes in facial gingival levels than sites with thin gingival biotypes at 1 year after placement $(-0.25 \mathrm{~mm}$ versus $-0.75 \mathrm{~mm}$ respectively) and at the 4 year follow up $(-0.56 \mathrm{~mm}$ and $-1.50 \mathrm{~mm}$ respectively).

Connective tissue grafts placed concurrently with implant placement in thick or thin tissue made gingival tissues more resistant to recession, according to Kan et al. (2009). Thick tissue showed a gain of $0.23 \mathrm{~mm}$ while thin tissue showed a gain of 0.06 
mm. Kim et al. (2009) found more recession with the deficient keratinized tissue $(\leq 2$ $\mathrm{mm}$ ) than sufficient keratinized tissue $(>2 \mathrm{~mm}$ ) and reported recession of $0.72 \mathrm{vs} .0 .32$ $\mathrm{mm}$, respectively. Therefore a sufficient amount of keratinized tissue is of great interest regarding esthetic outcome (Grunder et al. 2005). Biotype conversion by increasing the quality and quantity of the facial gingival tissue with SCTG might be beneficial for facial gingival stability.

Implant placement can be performed by either an immediate or delayed approach and by means of a flap or flapless approach. Studies have shown conflicting results with regard to tissue recession associated with immediately placed implants. De Rouck et al. (2009) reported mid-facial recession around implants was 2.5 to 3 times greater following delayed restoration when compared to immediate restoration after one year, showing a mean difference of $0.75 \mathrm{~mm}$ at 1 year, favoring immediate restoration.

Raes et al. (2011), compared immediate and delayed single implants in the maxillary anterior. At 1 year, immediate vs. delayed showed a mean mid-facial recession of (-0.12 vs. $-1.00 \mathrm{~mm})$. Advanced mid-facial recession exceeding $1 \mathrm{~mm}$ was found in $7 \%$ of immediately installed implants and $43 \%$ of delayed implants. Immediate implants installed with a flapless approach showed significantly less mid-facial recession when compared with a flap procedure at 1 year (mean difference $0.89 \mathrm{~mm}$ ). Recession data from previous studies is reported in Table 3. 
Table 3

\section{1- to 5-year Facial Recession Data}

\begin{tabular}{|c|c|c|c|c|c|}
\hline Study & Year & Implants & $1 \mathrm{yr}$ & 1.5-2.0 yrs & 3-5 yrs \\
\hline Bengazi et al. & 1996 & 158 & & 0.50 & \\
\hline Bengazi et al. & 1996 & 158 & & 0.60 & \\
\hline Grunder & 2000 & 10 & 0.60 & & \\
\hline Small and Tarnow & 2000 & 63 & 0.88 & & \\
\hline Small et. al. & 2001 & 150 & & & 0.73 \\
\hline Small et. al. & 2001 & 62 & & & 1.58 \\
\hline Zitzmann et al. & 2001 & 112 & 0.06 & & 0.01 \\
\hline Oates et al. & 2002 & 106 & 0.70 & 0.90 & \\
\hline Giannopoulou et al. & 2003 & 61 & -0.20 & & -0.30 \\
\hline Kan et al. & $2003 a$ & 35 & 0.55 & & \\
\hline Priest & 2003 & 55 & 0.13 & & 0.06 \\
\hline Gotfredsen & 2004 & 10 & & & 0.30 \\
\hline Gotfredsen & 2004 & 10 & & & -0.30 \\
\hline Cardaropoli et al. & 2006 & 11 & 0.60 & & \\
\hline Weber et al. & 2006 & 59 & 0.28 & & 0.30 \\
\hline Weber et al. & 2006 & 93 & -0.04 & & -0.02 \\
\hline Canullo and Rasperini & 2007 & 10 & -0.20 & & \\
\hline Cooper et al. & 2007 & 43 & -0.34 & & -0.51 \\
\hline Hall et al. & 2007 & 14 & 0.67 & & \\
\hline Hall et al. & 2007 & 14 & 0.33 & & \\
\hline Evans and Chen & 2008 & 42 & & 0.90 & \\
\hline Palattella et al. & 2008 & 9 & 0.60 & & \\
\hline Palattella et al. & 2008 & 9 & 0.80 & & \\
\hline Zigdon and Machtei & 2008 & 22 & 0.90 & & 0.90 \\
\hline Zigdon and Machtei & 2008 & 41 & 0.45 & & 0.27 \\
\hline Zigdon and Machtei & 2008 & 25 & 0.27 & & 0.90 \\
\hline Zigdon and Machtei & 2008 & 38 & 0.90 & & 0.45 \\
\hline Kan et al. & 2009 & 12 & & -0.06 & \\
\hline Kan et al. & 2009 & 8 & & -0.23 & \\
\hline Kim et al. & 2009 & 90 & 0.72 & & \\
\hline Kim et al. & 2009 & 186 & 0.32 & & \\
\hline DeRouck et al. & 2009 & 25 & 0.41 & & \\
\hline DeRouck et al. & 2009 & 24 & 1.16 & & \\
\hline Nisapakuhorn et al. & 2010 & 40 & 0.50 & & \\
\hline Raes et al. & 2011 & 39 & 1.00 & & \\
\hline Raes et al. & 2011 & 39 & 0.12 & & \\
\hline Kan et al. & 2011 & 14 & 0.25 & & 0.56 \\
\hline Kan et al. & 2011 & 21 & 0.75 & & 1.50 \\
\hline Gallucci et al. & 2011 & 10 & 0.85 & 0.96 & \\
\hline Gallucci et al. & 2011 & 10 & 0.60 & 0.50 & \\
\hline Chung et al. & 2011 & 10 & 0.05 & & \\
\hline Cosyn et al. & 2011 & 28 & 0.53 & & \\
\hline Cosyn et al. & 2011 & 25 & & & 0.34 \\
\hline Mean \pm sd & & $46 \pm 46$ & $0.5 \pm 0.4$ & $0.5 \pm 0.5$ & $0.4 \pm 0.6$ \\
\hline $\mathbf{n}$ & & 43.0 & 33.0 & 8.0 & 17.0 \\
\hline
\end{tabular}


Anatomy and Biologic Width. The gingival and alveolar bone in the maxillary anterior region plays an important role in determining the final esthetic outcome. The periodontium has been described as having two basic forms: "scalloped thin" or "flat thick" (Ochsenbein and Ross, 1969). Olsson and Lindhe (1991) referred to these as periodontal biotypes and found the "thick flat" periodontal biotype to be more prevalent than the "scalloped thin" form ( $85 \%$ to $15 \%$ ). The contour and form of the gingiva is closely followed the contour of the underlying bone. The stability of the osseous crest and position of the free gingival margin are directly proportional to the thickness of the bone and gingival tissues.

Becker et al. (1997) evaluated 111 dry skulls and divided them into flat, scalloped and pronounced scalloped anatomic profiles according to alveolar bone anatomy. The mean distance from the height of the interdental bone to the mid-radicular alveolar crest was significantly different $(\mathrm{p}<0.05)$ when the groups were compared (flat $2.1 \mathrm{~mm}$, scalloped $2.8 \mathrm{~mm}$, pronounced scallop $4.1 \mathrm{~mm}$ ). The degree of scallop is important in implant dentistry because after tooth extraction thick-flat anatomic profiles result in subtle changes in bone and overlying mucosa. Scalloped and thin profiles are more suscepitible to facial recession and loss of interproximal tissue. In contrast, thick tissue is more resistant to trauma and subsequent recession allowing greater tissue manipulation, encouraging creeping attachment and improving papilla fill.

The contour and form of the gingiva closely followed the contour of the underlying bone. According to Kois (2001a), in the healthy periodontium, the underlying bony crest is about $2 \mathrm{~mm}$ apical to the cementoenamel (CEJ) junction and follows the scallop of the CEJ. Compared with the normal or high gingival scallop, flat gingival 
architecture has less tissue coronal to the bone interproximally and facially. It tends to follow the osseous scallop creating less discrepancy and less risk of interproximal tissue loss and facial recession. These key bone, tissue and biotype interrelationships can determine the stability of the tissues as well as the final clinical outcome. Maintaining optimal esthetics and function for implant supported restorations is dependent on the interrelationships between the underlying crestal bone, overlying tissues and biotype.

\section{Table 4}

\section{Anatomy of Teeth in the Esthetic Zone}

\begin{tabular}{|l|c|c|c|c|c|c|c|}
\hline & $\begin{array}{c}\text { Crown } \\
\text { length }\end{array}$ & $\begin{array}{c}\text { M-D } \\
\text { Crown } \\
\text { Width }\end{array}$ & $\begin{array}{c}\text { M-D } \\
\text { Diameter } \\
\text { at CEJ }\end{array}$ & $\begin{array}{c}\text { B-L } \\
\text { Diameter }\end{array}$ & $\begin{array}{c}\text { B-L } \\
\text { Diameter } \\
\text { at CEJ }\end{array}$ & $\begin{array}{c}\text { Curvature } \\
\text { of CEJ on } \\
\text { M }\end{array}$ & $\begin{array}{c}\text { Curvature } \\
\text { of CEJ on } \\
\text { D }\end{array}$ \\
\hline Central & 10.5 & 8.5 & 7.0 & 7.0 & 6.0 & 3.5 & 2.5 \\
\hline Lateral & 9.0 & 6.5 & 5.0 & 6.0 & 5.0 & 3.0 & 2.0 \\
\hline Canine & 10.0 & 7.5 & 5.5 & 8.0 & 7.0 & 2.5 & 1.5 \\
\hline $\begin{array}{l}1^{\text {st }} \\
\text { premolar }\end{array}$ & 8.5 & 7.0 & 5.0 & 9.0 & 8.0 & 1.0 & 0.0 \\
\hline $\begin{array}{l}2^{\text {nd }} \\
\text { premolar }\end{array}$ & 8.5 & 7.0 & 5.0 & 9.0 & 8.0 & 1.0 & 0.0 \\
\hline
\end{tabular}

*Adapted from text by Wheeler

First described by Gargiulo et al. (1961), biologic width is the term applied to the dimensional width of the dentogingival complex, which combined the epithelial attachment and underlying connective tissue. Gargiulo et al. (1961) studied the anatomy

of the dentogingival complex and quantified that biologic width consists of a mean of $1.07 \mathrm{~mm}$ connective tissue, a mean of $0.97 \mathrm{~mm}$ epithelial attachment, and a mean sulcus depth of $0.69 \mathrm{~mm}$. 
The biologic width around teeth and implants has been studied and is important to consider when placing implants in the esthetic zone. In order to have a healthy situation, around both implants and teeth, the principles of biologic width need to be followed. Cochran et al. (1997) examined histologically the biologic width dimensions in 6 foxhounds using 1-stage, Straumann TPS and SLA implants loaded at 3 months and followed up to 12 months and reported the biologic width of implants to be greater than that of teeth. Biologic width consisted of a mean of $1.05 \mathrm{~mm}$ connective tissue, $1.88 \mathrm{~mm}$ epithelial attachment, and $0.16 \mathrm{~mm}$ sulcus depth (approximately $2.93 \mathrm{~mm}$ ). Romanos et al. (2010) studied biologic width around 12 immediately loaded implants in a human autopsy specimen after 7 months of loading. A difference in the soft tissue organization around dental implants for the upper and lower jawbones was reported. The biologic width, including the sulcus, in the maxilla was $6.5 \pm 2.5 \mathrm{~mm}$, whereas in the mandible, it was $4.8 \pm 1.3 \mathrm{~mm}$. The junctional epithelium (JE) in the maxilla was $1.3 \pm 0.4 \mathrm{~mm}$ and $1.5 \pm 0.5 \mathrm{~mm}$ in the mandible. This value is less than reported previously by Cochran et al. (1997). The connective tissue (CT) in the maxilla was $2.5 \pm 1.3 \mathrm{~mm}$, whereas in the mandible, it was $1.6 \pm 0.4 \mathrm{~mm}$, revealing a greater connective tissue compartment as compared to Cochran et al. (1997). In the maxillary arch, the biologic width, sulcular epithelium and connective tissue were significantly longer as compared to the mandibular arch.

\section{Implant Design}

Rationale for the LaserLok Collar Design. Various dental implant designs have been devised to preserve crestal bone and limit the apical migration of the junctional 
epithelium at the implant-abutment junction. Precisely configured microchannels placed within an implant collar or healing abutment may help achieve these goals. The LaserLok (BioHorizons) microtextured collar was developed to minimize crestal bone loss on a reverse buttress-threaded implant. The Laser-Lok microchannels consist of precise, three-dimensional microstructures formed by a computer-controlled laser ablation technique that creates a series of microgrooved channels to optimally control the orientation of attached cells. This patented laser surface treatment has been shown to inhibit epithelial downgrowth, attach and retain crestal bone and provide for biologic width and soft tissue attachment. The Laser-Lok microchannels are the result of over 15 years of research and documented studies (Brunette et al. 1999).

BioHorizon's standard implant originally had a $1.5 \mathrm{~mm}$ polished collar, which was subsequently replaced with 8 and 12 micron grooves. The coronal $0.7 \mathrm{~mm}$ wide zone of 8 micron cell-sized channels allows for soft tissue adhesion/attachment, providing an epithelial barrier and promoting connective tissue adhesion/attachement. The apical 0.8 mm wide zone of 12 micron cell-sized channels promotes bone cell attachment and retention of crestal bone (Brunette et al. 1999). In. January 2011, a change was made to the implant eliminating the smooth, machined area now featuring a full $1.8 \mathrm{~mm}$ LaserLok collar with 8 and 12 micron microchannels. The most recent change is the Tapered Internal Plus Implant System, which will be available November 2012. This system offers the benefits of the tapered system and a Laser-Lok treated beveled-collar with a platform switched design.

Implant Surface. In 1997, BioHorizons pioneered the use of a resorbable blast textured (RBT) surface, which has been shown to improve bone cell contact as compared 
to machined titanium surfaces. The tapered internal hex implants are manufactured with a RBT surface and Laser-Lok micron sized channels at the implant neck. The (RBT) surface is a roughened surface designed to increase biologic fixation and to maximize implant-to-bone contact. A biocompatible calcium phoshate is used to blast the surface which resorbs during the passivation process leaving the optimum roughness profile of a pure $\mathrm{TiO}_{2}$ surface.

Microgrooves. The most significant effects on the attachment, orientation and growth of fibroblasts and osteoblasts was reported with microgrooved surfaces with groove widths and depths in the range of 6 to 12 microns (Weiner et al. 2008). These precision-engineered cell-sized channels were found to optimally control the orientation of the cells. The 12 micron channels showed the best potential for inhibition of fibrous tissue growth relative to bone cell growth, and 8 micron channels showed the most effective inhibition of epithelial cell migration across the grooves and promote connective tissue attachment. The laser micro-grooved surfaces showed less fibrous encapuslation and greater bone integration when compared to machined-collar implants.

While other implant surfaces have demonstrated greater osseointegration when compared to machined, smooth surface implants, only the Laser-Lok surface has shown through the use of light microscopy, polarized light and scanning electron microscopy the potential for connective tissue attachment, (Nevins et al. 2008). Between the apical termination of the junctional epithelium and the alveolar bone crest, connective tissue directly apposed the implant surface. Light microscope evaluation revealed intimate contact of the junctional epithelial cells with the implant surface. The microgrooved area of the implants was covered with connective tissue. Polarized light microscopy of this 
area showed functionally oriented collagen fibers running toward the grooves of the implant. All specimens established a high degree of bone-to-implant contact, collagen fibers were functionally oriented toward the grooves on the implant surface, and remodeling of new bone in the coronal direction was observed. Scanning electron microscopy confirmed the attachment of supracrestal connective tissue to the microchannels, which is determined to be instrumental in preserving crestal alveolar bone and inhibiting apical migration of the epithelium. Recently, scanning electron microscopy (SEM) has revealed that there is no significant difference between 8 and 12 micron grooves in gaining soft/hard tissue attachment. This evidence resulted in a manufacturing change. Now, the tapered internal implants with Laser-Lok (TLX) have a $1.8 \mathrm{~mm}$ laser micromachined surface consisting of 8 micron grooves the entire length.

In a study by Botos et al. (2011) comparing the effects of laser microtexturing on the implant collar on crestal bone levels and peri-implant health, two implant systems were compared: An implant with a laser micro-textured collar (Bio-Loc, Laser-Lok) and an implant with a machined collar (Nobel, Replace Select). Data at 6 and 12 months revealed that the application of laser-microtextured grooves to the implant collar resulted in shallower pocket depths and less peri-implant crestal bone loss as compared to implants with machined collars.

Abutment Design: Rationale for Laser Microgrooved Abutments. The establishment of a physical, connective tissue attachment to the Laser-Lok surface has generated an entirely new area of research and development: Laser-Lok applied to abutments. Nevins et al. (2012) conducted a human histologic study assessing the CT attachment to laser-microgrooved abuments. As in his previous preclinical canine study 
Nevins et al. (2010), the presence of a $0.7 \mathrm{~mm}$ wide laser ablated 8 to 12 micron deep microchanneled zone resulted in a more functional orientation of the peri-abutment connective tissue fibers. This change in directional orientation served as an anatomical barrier inhibiting the apical migration of junctional epithelium (JE), decreasing the inflammatory sequlae found at the implant abutment junction (IAJ) microgap, resulting in crestal bone stability.

\section{Treatment Planning}

Presence of Papilla. Jemt (1997) proposed an index to clinically evaluate the extent of recession and regeneration of the interproximal gingival papillae adjacent to single implant restorations. The results of the study indicated a spontaneous regeneration of papilla $(\mathrm{p}<.001)$ after a mean follow-up period of 1.5 years. The results also indicated that soft tissue changed in a systematic manner during the time period between insertion of crown and at follow-up visits 1-3 years later. This proposed index allows scientific assessment of soft tissue contour adjacent to single-implant restorations.

Index score 0: No papilla is present, and there is no indication of a curvature of the soft tissue contour adjacent to the single-implant restoration.

Index score 1: Less than half of the height of the papilla is present. A convex curvature of the soft tissue contour adjacent to the single implant crown and the adjacent tooth is observed.

Index score 2: At least half of the height of the papilla is present, but not all the way up to the contact point between the teeth. Papilla is not completely in harmony with the adjacent papillae between the permanent teeth. 
Index score 3: The papilla fills up the entire proximal space and is in good harmony with the adjacent papillae. There is optimal soft tissue contour.

Index score 4: The papillae are hyperplastic and cover too much of the single implant restoration and/or the adjacent tooth. The soft tissue contour is more or less irregular.

Table 5 below includes the papilla fill results from various studies ranging from 6 months to 3-5 years post crown delivery. 


\section{Table 5}

Papilla Fill from Insertion to 5 years

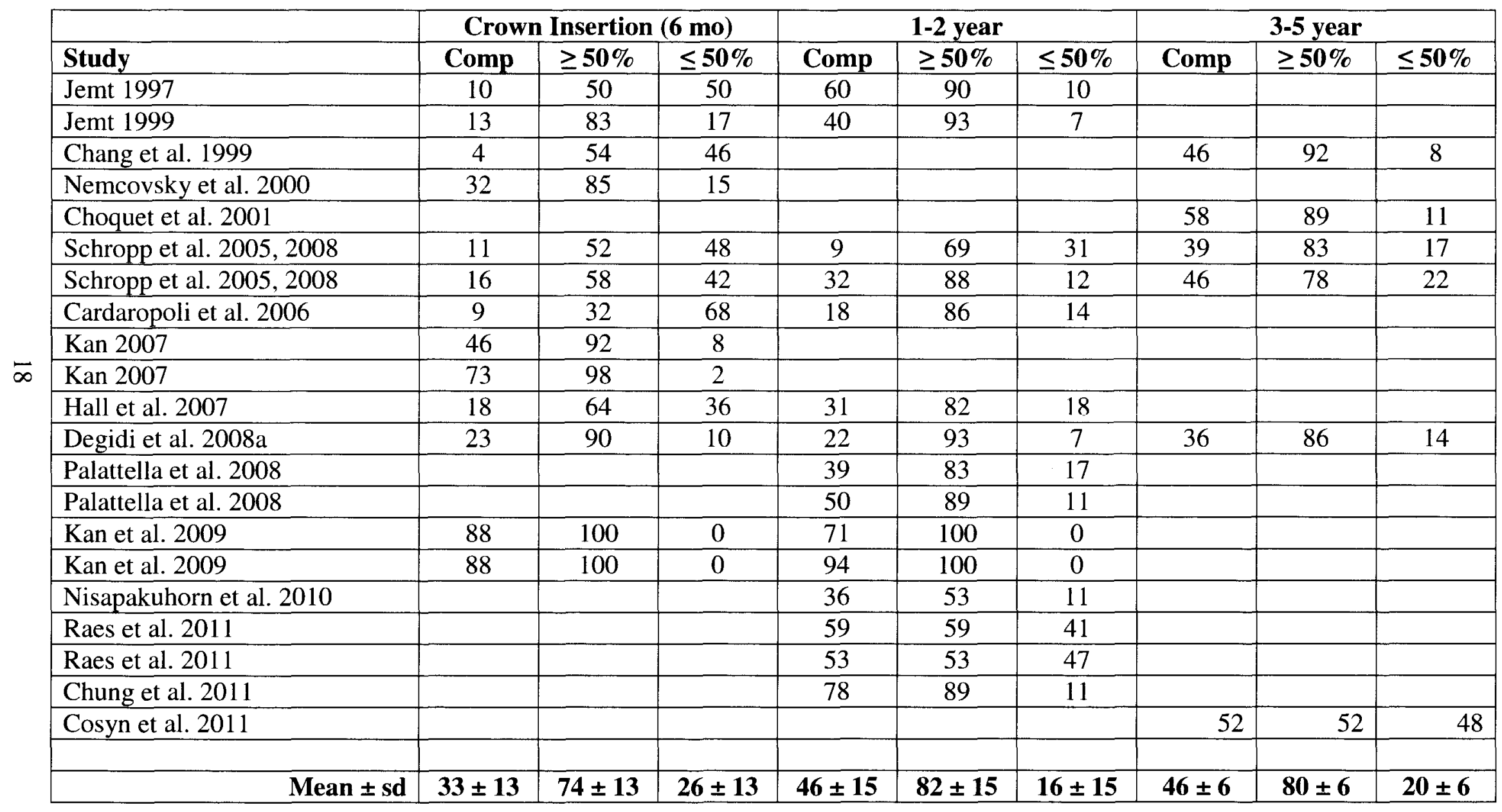


Predictable soft tissue margins and the preservation of papillae around dental implants is a major concern in periodontal plastic surgery and in restorative dentistry. Reconstruction in a patient with a high lip line smile with the loss of the interdental papilla in the esthetic zone is one of the most challenging goals for the practitioner. The presence and height of the papilla is dependent on several factors. Crestal bone height, interproximal distance, tooth form/shape, gingival thickness, and keratinized tissue width have been identified to influence the appearance of the interimplant papillae (Chow and Wang 2010).

A study conducted by Jemt (1997) evaluating healing following implant placement and provisionalization, revealed that on average about half of the height of the papilla was lost (mean index 1.5) when the soft tissue was allowed to heal completely around the temporary abutment prior to crown fabrication. After 1-3 years, a spontaneous regeneration was observed with $58 \%$ of the papillae completely recovered and in harmony with the adjacent natural teeth. Chang et al. (1999) evaluated crown and soft tissue dimensions between implant-supported single-tooth restorations and the contralateral natural teeth in the maxillary esthetic zone in 20 patients. At crown placement $4 \%$ had complete papilla fill and at 38-month follow-up this increased to $46 \%$. He reported papilla fill $\geq 50 \%$ at crown insertion that changed from $54 \%$ to $92 \%$ at 38 months.

Schropp et al. 2008 evaluated papilla levels of 45 patients that had either early (mean 10 days post tooth extraction) or delayed ( 3 months after tooth extraction) implant placement over a 5-year period. In the early group, only $9 \%$ of the papillae were negative or lacking (score 0) versus $19 \%$ in the delayed group. A continuous improvement of the 
papilla height occurred within the 5-year observational period and no differences between the groups were observed at 5 years after implant placement.

Cosyn et al. (2011) assessed the hard and soft tissue dynamics and the esthetic outcome of 25 immediate single-tooth implants placed in the maxillary anterior. At 3year follow-up $52 \%$ of sites showed complete papilla fill. Mean mesial/distal papilla shrinkage in reference to pre-operative status accounted for 0.05 and $0.08 \mathrm{~mm}$. Significant papillary re-growth was observed between 1- and 3-year reassessment. Mesial /distal papilla growth was $0.36 \mathrm{~mm}$ and $0.23 \mathrm{~mm}$, respectively.

Kan et al. (2011) examined the gingival tissue stability following immediate placement and provisionalization of 35 maxillary anterior implants with a mean followup of 4 years. Data revealed that flapless immediate implant placement was beneficial as demonstrated by the minimal mean overall mesial papilla level and distal papilla level changes $(-0.22 \mathrm{~mm}$ and $-0.21 \mathrm{~mm}$, respectively), which were significantly smaller than those changes $(-0.53 \mathrm{~mm}$ and $-0.39 \mathrm{~mm})$ seen at the 1-year follow-up visit. These findings are in agreement with other studies reporting spontaneous papilla regeneration.

Kan et al. (2009) conducted a study in which 20 consecutive patients who had undergone immediate single tooth replacement with connective tissue grafting, soft tissue changes and biotypes were evaluated. At a mean follow-up of 2.15 years, $100 \%$ of the sites had $\geq 50 \%$ papilla fill while $80 \%$ of the sites had complete papilla fill, validating the efficacy of immediate tooth replacement in preserving the interproximal papilla. In addition, patients exhibited thick biotype morphology. However, no significant differences were observed between the initially thin or thick gingival biotypes when comparing changes in mean facial gingival levels. 
Chung et al. (2011) also evaluated immediate single tooth implant placement and provisionalization with subepithelial connective tissue grafts in 10 patients. At 1-year follow-up, more than $50 \%$ of the papilla was observed in $89 \%$ of the sites, while $78 \%$ had complete papilla fill. There were no statistically significant differences in the papilla index scores at different time intervals $(0,3,6,12$ months) even when necrosis of the connective tissue graft occurred in $2 / 10$ patients. These results support the previous concept that peri-implant papilla levels are determined by the proximal bone levels of the adjacent teeth and that the ideal way to maintain the papilla is to provide hard tissue support immediately after tooth extraction.

Lee et al. (2012) examined soft tissue levels of changes following the placement of 11 immediate implants in the maxillary incisor zone with a simultaneous connective tissue (CT) graft and provisionalization with a 2-year mean follow-up. Results demonstrated that papilla levels showed an increase in height from time of crown connection to the 2 year follow-up visit. Gingival papilla regeneration was on average 0.5 $\mathrm{mm}$ mesially and $0.3 \mathrm{~mm}$ distally. $23 \%$ of sites had $\geq 50 \%$ papilla fill at time of crown placement and $36 \%$ of sites had complete papilla fill at 2-year follow-up visit.

Salama and Garber (1998) presented prognostic criteria that emphasized the osseous-gingival relationship to achieve predictable esthetic results in the anterior region. They reported the necessary horizontal and vertical interproximal dimensions to obtain papilla formation under a variety of tooth, implant, or pontic relationships (Table 6). 
Table 6

\section{Horizontal and Vertical Bone Distance for Predictable Papilla Formation}

\begin{tabular}{|c|c|c|}
\hline $\begin{array}{c}\text { Restorative } \\
\text { Environment }\end{array}$ & Horizontal Distance & $\begin{array}{c}\text { Vertical Crest to } \\
\text { Contact Distance }\end{array}$ \\
\hline & & mean \\
\hline Tooth - Tooth & $1 \mathrm{~mm}$ & 5.0 \\
\hline Tooth - Pontic & & 6.5 \\
\hline Pontic - Pontic & & 6.0 \\
\hline Tooth - Implant & $1.5 \mathrm{~mm}$ & 4.5 \\
\hline Implant - Pontic & & 5.5 \\
\hline Implant - Implant & $3 \mathrm{~mm}$ & 4.5 \\
\hline
\end{tabular}

Kan et al. (2003b) measured the peri-implant mucosal dimensions of 45 implants placed in the maxillary anterior. Peri-implant biotypes were also evaluated and categorized as thick and thin. He concluded that the level of the interproximal papilla is independent of the proximal bone level next to the implant, but is related to the interproximal bone level next to the adjacent teeth. The papilla heights between thick and thin biotypes were compared after 1 year of function and reported in Table 7.

\section{Table 7}

\section{Papilla Height Relative to Periodontal Biotype}

\begin{tabular}{|l|c|c|}
\hline Kan et al. 2003b & Mesial & Distal \\
\hline Mean papilla height & $4.2 \mathrm{~mm}$ & $4.2 \mathrm{~mm}$ \\
\hline Thick Biotype & $4.5 \mathrm{~mm}$ & $4.5 \mathrm{~mm}$ \\
\hline Thin Biotype & $3.8 \mathrm{~mm}$ & $3.8 \mathrm{~mm}$ \\
\hline
\end{tabular}

Tarnow et al. (1992), examined the distance from the contact point to the crest of bone and its effects on the presence or absence of the dental papilla on 288 interproximal sites. Results demonstrated that the papilla was present almost $100 \%$ of the time when the 
distance from the contact point to the crest of the bone was $5 \mathrm{~mm}$ or less. When the distance was $6 \mathrm{~mm}$, the papilla was present $56 \%$ of the time, and when the distance was 7 $\mathrm{mm}$ or more, the papilla was present $27 \%$ of the time.

Choquet et al. (2001) reported similar results when evaluating papilla levels of single tooth dental implants and their adjacent teeth in the maxillary anterior region. When the measurement from the contact point to the crest of bone was $5 \mathrm{~mm}$ or less, the papilla was present almost $100 \%$ of the time. If the distance was $\geq 6 \mathrm{~mm}$, the papilla was present $50 \%$ of the time or less. According to Gastaldo et al. (2004), the ideal distance from the bone crest to the base of the contact between a tooth and implant should be 3-5 $\mathrm{mm}$.

Tarnow et al. (2003) examined the papillary heights between two adjacent implants in 136 sites in 33 patients and determined the mean height was only $3.4 \mathrm{~mm}$, with a range of 1 to $7 \mathrm{~mm}$. The soft tissue heights were 2,3 , or $4 \mathrm{~mm}$ in $90 \%$ of the cases. It was concluded that the ideal distance from the base of contact to bone crest between implants is $3 \mathrm{~mm}$. 
Table 8 below includes several studies that present papilla fill in relation to the distance from crest to contact point.

Table 8

Tooth-Implant Papilla Fill Relative to Osseous Crest to Contact Distance

\begin{tabular}{|r|c|c|c|c|c|c|c|c|c|}
\hline $\begin{array}{c}\text { Tooth- } \\
\text { Implant }\end{array}$ & $\begin{array}{c}\text { Choquet } \\
\text { et al. 2001 }\end{array}$ & $\begin{array}{c}\text { Gastaldo } \\
\text { et al. 2004 }\end{array}$ & $\begin{array}{c}\text { Ryser et } \\
\text { al. 2005 }\end{array}$ & $\begin{array}{c}\text { Lops et } \\
\text { al. 2008 }\end{array}$ & $\begin{array}{c}\text { Romeo } \\
\text { et al. } \\
\mathbf{2 0 0 8}\end{array}$ & $\begin{array}{c}\text { Degidi } \\
\text { et al. } \\
\mathbf{2 0 0 8 b}\end{array}$ & $\begin{array}{c}\text { Kawai, } \\
\text { Almeida } \\
\mathbf{2 0 0 8}\end{array}$ & Mean & n \\
\hline Time & 1 year & $\begin{array}{c}1.5-6 \\
\text { years }\end{array}$ & 2 year & 1 year & 1 year & $\begin{array}{c}3-5 \\
\text { year }\end{array}$ & $\begin{array}{c}>4 \\
\text { months }\end{array}$ & & \\
\hline $\begin{array}{l}\text { Mean } \\
\text { Time }\end{array}$ & 1 & 4 & 2 & 1 & 1 & 4 & 0.5 & $\mathbf{1 . 9}$ & 7 \\
\hline $\begin{array}{l}\text { Crest to } \\
\text { contact } \\
\text { (mm) }\end{array}$ & & & & & & & & & \\
\hline$<5$ & 100 & 100 & 100 & & 67 & 92 & 92 & $\mathbf{9 1 . 8}$ & $\mathbf{6}$ \\
\hline$\leq 5$ & 100 & 100 & & 80 & & & & $\mathbf{9 3 . 3}$ & 3 \\
\hline 5 & 88 & 80 & 88 & & & 93 & 77 & $\mathbf{8 5 . 2}$ & 5 \\
\hline 5 to 7 & & & & & 67 & & & $\mathbf{6 7 . 0}$ & 1 \\
\hline 6 & 50 & 40 & 85 & & & 91 & & $\mathbf{6 6 . 5}$ & 4 \\
\hline $6+$ & & & & 52 & & & 75 & $\mathbf{6 3 . 5}$ & 2 \\
\hline 7 & 75 & 40 & 91 & & 33 & 89 & & $\mathbf{6 5 . 6}$ & 5 \\
\hline $7+$ & & & & 58 & 33 & & & $\mathbf{4 5 . 5}$ & 2 \\
\hline 8 & 50 & 40 & 75 & & & 50 & & $\mathbf{5 3 . 8}$ & 4 \\
\hline 9 & 50 & & 100 & & & & & $\mathbf{7 5 . 0}$ & 2 \\
\hline $10+$ & 75 & 25 & 0 & & & & & $\mathbf{3 3 . 3}$ & 3 \\
\hline
\end{tabular}

Several factors can affect both the dimensions and the existence of the periimplant papilla and papilla fill. One factor, in particular, is the papillae between implants or between tooth and implant is the horizontal distance between these elements. Kawai and Almeida (2008) observed that $80.8 \%$ of papilla had maximum filling of the interproximal space between tooth and implant when the horizontal distance was between 1.0 and $2.0 \mathrm{~mm}$. When there was a horizontal distance of 2.0 to $3.0 \mathrm{~mm}$, only $58.3 \%$ papilla fill was observed, which was also reported by Ryser et al. (2005). This is in disagreement with Gastaldo et al. (2004), who reported that when the horizontal distance was less then $3.0 \mathrm{~mm}$, papilla were absent $100 \%$ of the time. Lops et al. (2008), reported 
that a 1.0 to $2.5 \mathrm{~mm}$ horizontal distance between an implant and the adjacent tooth resulted in inter-proximal papilla present only $32 \%$ of the time. In contrast, 3.0 to $4.0 \mathrm{~mm}$ horizontal distances were associated with a full interproximal papilla ( $84.2 \%$ of the time).

Table 9

Papilla Fill Relative to the Tooth-Implant Horizontal Distance

\begin{tabular}{|r|c|c|c|c|c|c|}
\hline $\begin{array}{c}\text { Tooth- } \\
\text { Implant }\end{array}$ & $\begin{array}{c}\text { Gastaldo } \\
\text { et al. 2004 }\end{array}$ & $\begin{array}{c}\text { Lops et } \\
\text { al. 2008 }\end{array}$ & $\begin{array}{c}\text { Romeo et } \\
\text { al. 2008 }\end{array}$ & $\begin{array}{c}\text { Kawai, } \\
\text { Almeida } \\
\mathbf{2 0 0 8}\end{array}$ & Mean & n \\
\hline Time & $\begin{array}{l}1.5 \text { to } 6 \\
\text { years }\end{array}$ & 1 year & 1 year & $\begin{array}{c}>4 \\
\text { months }\end{array}$ & & \\
\hline Mean Time & 4 & 1 & 1 & 0.5 & $\mathbf{1 . 6}$ & 4 \\
\hline $\begin{array}{r}\text { Implant to } \\
\text { tooth distance }\end{array}$ & & & & & & \\
\hline 0 to 1 mm & & & & 100 & $\mathbf{1 0 0 . 0}$ & 1 \\
\hline 1 to 2.5 & & 32 & 35.7 & & $\mathbf{3 3 . 9}$ & 2 \\
\hline 2 & 0 & & & 80.8 & $\mathbf{4 0 . 4}$ & 2 \\
\hline 2.5 & 0 & & & & $\mathbf{0 . 0}$ & 1 \\
\hline 3 & 88 & & & 58 & $\mathbf{7 3 . 0}$ & 2 \\
\hline 3 to 4 & & 84.2 & 77.7 & 50 & $\mathbf{7 0 . 6}$ & 3 \\
\hline 3.5 & 83 & & & & $\mathbf{8 3 . 0}$ & 1 \\
\hline 4 & 75 & & & 50 & $\mathbf{6 2 . 5}$ & 2 \\
\hline$>4$ & & 70 & 57.1 & & $\mathbf{6 3 . 6}$ & 2 \\
\hline 4.5 & 56 & & & & $\mathbf{5 6 . 0}$ & 1 \\
\hline 5 to 6 & & & & 0 & $\mathbf{0 . 0}$ & 1 \\
\hline $6+$ & & & & 2.2 & $\mathbf{2 . 2}$ & 1 \\
\hline
\end{tabular}

Tarnow et al. (2000) evaluated the effects of the inter-implant distance on the inter-implant crestal bone heights and found that there was a lateral component to bone loss around implants. It was reported that the critical inter-implant distance was $3.0 \mathrm{~mm}$. It was concluded that this inter-implant distance plays a significant role in the presence and appearance of papilla. Lee et al. (2006) also examined papilla height between 
implants. Results showed that if the horizontal distance between implants was $<3 \mathrm{~mm}$ then the mean papilla height was $3 \mathrm{~mm}$ or less. When the implants were $\geq 3 \mathrm{~mm}$ apart the mean papilla height was $3 \mathrm{~mm}$ or greater.

Gastaldo et al. (2004) examined the effects of vertical and horizontal distances between adjacent implants and between a tooth and an implant and the presence of papilla. It was reported the ideal lateral spacing between implants was 3 to $4 \mathrm{~mm}$. He also concluded that the ideal distance from the base of the contact point to the bone crest between adjacent implants is $3 \mathrm{~mm}$ and, between a tooth and an implant was 3 to $5 \mathrm{~mm}$. Degidi et al. (2008b) reported in 2 adjacent immediately placed and immediately loaded implants, the contact point between the two prosthetic crowns should be placed at 3 to 4 $\mathrm{mm}$, and never $>6 \mathrm{~mm}$, from the bone crest. Two adjacent implants should be placed at a distance $>2$ and $<4 \mathrm{~mm}$.

The percent of sites with $\geq 50 \%$ papilla fill with varying alveolar crest to contact distances as well as the percent of sites with $\geq 50 \%$ papilla fill with varying horizontal distances between 2 implants are reported in Tables 10 and 11 . 
Table 10

Implant-Implant Papilla Fill Relative to Osseous Crest to Contact Distance

\begin{tabular}{|l|c|c|c|c|}
\hline $\begin{array}{l}\text { Implant- } \\
\text { Implant }\end{array}$ & $\begin{array}{l}\text { Gastaldo et al. } \\
\mathbf{2 0 0 4}\end{array}$ & $\begin{array}{c}\text { Degidi et al. } \\
\mathbf{2 0 0 8 b}\end{array}$ & Mean & $\mathrm{n}$ \\
\hline Time & $1.5-6$ years & 2 years & & \\
\hline Mean Time & 4 & 2 & $\mathbf{3}$ & 2 \\
\hline $\begin{array}{l}\text { Crest to contact } \\
(\mathbf{m m})\end{array}$ & & & & \\
\hline$\leq 3$ & 100 & 94 & $\mathbf{9 7 . 0}$ & 2 \\
\hline 4 & 50 & 91 & $\mathbf{7 0 . 5}$ & 2 \\
\hline 5 & 40 & 80 & $\mathbf{6 0 . 0}$ & 2 \\
\hline 6 & 26 & 79 & $\mathbf{5 2 . 5}$ & 2 \\
\hline$>6$ & & 75 & $\mathbf{7 5 . 0}$ & 1 \\
\hline 7 & 40 & & $\mathbf{4 0 . 0}$ & 1 \\
\hline 8 & 40 & & $\mathbf{4 0 . 0}$ & 1 \\
\hline 10 & 25 & & $\mathbf{2 5 . 0}$ & 1 \\
\hline
\end{tabular}

Table 11

Implant-Implant Papilla Fill Relative to Horizontal Inter-implant Distance

\begin{tabular}{|c|c|}
\hline Implant-Implant & $\begin{array}{l}\text { Gastaldo et al. } \\
2004\end{array}$ \\
\hline Time & $1.5-6$ years \\
\hline \multicolumn{2}{|l|}{$\begin{array}{l}\text { Implant to implant } \\
\text { distance }\end{array}$} \\
\hline (2) & 0 \\
\hline 2.5 & 0 \\
\hline 3 & 82 \\
\hline 3.5 & 81 \\
\hline 4 & 71 \\
\hline 4.5 & 48 \\
\hline
\end{tabular}

Kois et al. (2001a) reported that tooth shape and form as one of the five essential diagnotic keys for peri-implant esthetics. The predictability of the peri-implant soft tissue architecture and esthetics can be determined by the presenting tooth anatomy. Tooth shape can be classified into three basic shapes; triangular, ovoid, and square. Tooth form, 
on the other hand, can be defined as long narrow or short wide. Olsson et al. (1993) concluded that individuals with the long narrow tooth form displayed thin free gingival, a narrow zone of keratinized tissue, shallow probing depth, and a pronounced scalloped contour of the gingival margin.

According to Kois (1994), tooth anatomy impacts the tissues both coronal and apical to the free gingival margin (FGM). Coronal to the FGM, the tooth shape will influence the volume and height of the gingival embrasure. Apical to the FGM, the tooth shape will influence the proximity of the roots and support the gingival tissue both facially and interproximally. Coronal to the FGM, the square tooth shape is the most favorable because the proximal contact is longer and more tooth structure fills the interdental area. The triangular tooth shape creates the highest risk for black triangles because the proximal contact point is more incisally positioned and would require more tissue height to fill the interproximal area. It is suggested by Kois (1994) that modification of the adjacent tooth shape with either direct composite or porcelain veneer after an implant-supported restoration. Triangular tooth shapes allow for roots that are positioned further apart, which provides potentially thicker interproximal bone. This may actually minimize loss of vertical bone height after extraction procedures and implant placement as a result of lateral resorption with lateral violation of biologic width. The ovoid and square tooth shape with proximal contact may therefore be at a greater risk of more vertical bone loss because the osseous crest is thinner. This shape, however, provides more proximal support for the interdental gingival tissue.

Site Selection. According to Kois (2001b), the predictability of the peri-implant esthetic outcome may ultimately be determined by the patient's own presenting anatomy 
rather than the clinician's ability to manage state-of-the-art procedures. He proposed five diagnostic keys for predictable single tooth peri-implant esthetics. These keys include: 1) relative tooth position, 2) periodontal form, 3) periodontal biotype, 4) tooth shape, and 5) osseous crest position. Any of these five keys can be combined or altered independently. Tooth position is evaluated based on its relative position to the remaining dentition in three planes of space because the existing tooth position will influence the presenting configuration of the gingival architecture. Form is divided into flat, scalloped, and pronounced scallop according to Kois (1994). Periodontal biotype is typically considered thick or thin. Tooth shape can be square, ovoid, or triangular. Position of the osseous crest will help predict future gingival levels after implant therapy.

\section{Implant Placement}

Incisions. Gomez-Roman (2001), compared 2 different flap designs: A widely mobilized flap design that included the papillae, and a limited flap design to protect the papillae and the extent of peri-implant interproximal crestal bone loss around single implants. It was reported that the amount of interproximal crestal bone loss occurring after placement of single-tooth implant varied using two different surgical designs. One

year after crown placement, mean interproximal bone loss for the widely mobilized flap design was $0.29 \mathrm{~mm}$ compared to $1.12 \mathrm{~mm}$ for the limited flap design. The limited flap design minimized the risk of papilla loss. The use surgical techniques that prevent esthetic complications, such as increased crown length or loss of interdental papilla, without compromising osseointegration are recommended.

Mesial-Distal Placement. The mesiodistal position of the implant has been thought to affect the appearance of the hard and soft tissue in the embrasure space. 
Tarnow et al. (2000) reported that there was a lateral component of bone loss around implants, in addition to the vertical component. It was reported that the mean horizontal bone loss around an implant was 1.3 to $1.4 \mathrm{~mm}$. It is because of this horizontal loss that an implant should be placed $\geq 1.5 \mathrm{~mm}$ from the tooth. The crestal bone loss for adjacent implants with an inter-implant distance of $3 \mathrm{~mm}$ or greater was $0.45 \mathrm{~mm}$, while implants with a distance of $3 \mathrm{~mm}$ or less had overlapping crestal bone loss of $1.04 \mathrm{~mm}$. Therefore, is was determined that a minimum of $3 \mathrm{~mm}$ was a critical inter-implant distance.

Buccolingual Position. Proper buccolingual positioning of the implant simplifies the restorative procedure, results in a proper emergence profile, and facilitates oral hygiene. An implant placed too far buccally often results in a dehiscence of the buccal cortical plate and has a high potential for gingival recession. Cardaropoli et al. (2006) evaluated dimensional alterations of the peri-implant tissue of single-tooth implants in the anterior maxillary region over 1 year. A mean reduction of $0.4 \mathrm{~mm}$ of the facial bone thickness and $0.7 \mathrm{~mm}$ of the facial bone height were observed between implant placement and second stage surgery. This was accompanied by a mean apical displacement of the facial soft tissue margin of $0.6 \mathrm{~mm}$. Spray et al. (2000) measured the vertical dimension of facial bone between implant placement and uncovering stage, comparing these changes to facial bone thickness. As the bone thickness approached 1.8 to $2 \mathrm{~mm}$, bone loss decreased significantly and some evidence of bone gain was seen. Based on these findings, they proposed that $2 \mathrm{~mm}$ of facial bone thickness should be left after implant placement to avoid future recession. Buser et al. (2004) recommended that the implant should be placed 1-2 $\mathrm{mm}$ lingual to the emergence of the adjacent teeth to ensure maintenance of an adequate width of buccal bone and stable mucosa over the buccal 
implant surface. Evans and Chen (2008) reported that implants placed in a buccal position exhibited three times more recession than implants with a lingual position.

Apicocoronal Positioning. Apical-coronal positioning or depth of the implant is required to mask the metal of the implant and the abutment and is an important factor in determining peri-implant tissue stability. This positioning may involve countersinking to provide sufficient emergence to allow a gradual transition between the implant platform and the contour of the restoration (emergence profile). Buser et al. (2004) stated that the apicocoronal positioning of the implant shoulder should follow the philosophy "as shallow as possible, as deep as necessary." Excessive countersinking or apical placement of the implant can cause saucerization, which is the undesirable circumferential vertical and horizontal crestal bone loss. This may lead to unnecessary bone loss on the adjacent tooth and subsequent gingival recession. Conversely, coronal placement of the implant can lead to visible metal margin and a compromised esthetic restoration. Saadoun (1997) recommended that implants should be placed 3 to $4 \mathrm{~mm}$ apical to the free gingival margin of the adjacent teeth to allow for adequate prosthetic emergence space and esthetics.

Platform Selection. Ideally, implant dimensions/diameter and position/level should replicate the root form and is critical for adequate support of peri-implant tissues and a favorable esthetic outcome. To achieve optimal tissue support and a cleansable emergence, the platform selected should be the widest that can be contained within the contours of the tooth and still provide a subtle flared emergence (London, 2001). Selecting an excessive diameter can result in compromise to the inter-proximal bone height, inadequate embrasure space for the papilla as well as for cleaning, and an 
unnatural tooth contour. Whereas, an undersized implant will provide inadequate support for soft tissue contours and difficult curette access for maintenance.

Table 12

\section{London's Optimal Implant Diameters}

\begin{tabular}{|l|l|l|l|}
\hline & $\begin{array}{l}\text { Small } \\
\text { Lateral }\end{array}$ & $\begin{array}{l}\text { Lateral, Small } \\
\text { Canine, } \\
\text { Premolar }\end{array}$ & $\begin{array}{l}\text { Canine, } \\
\text { Central }\end{array}$ \\
\hline $\begin{array}{l}\text { Optimal } \\
\text { Platform }\end{array}$ & $3.4 \mathrm{~mm}$ & $4.1 \mathrm{~mm}$ & $5 \mathrm{~mm}$ \\
\hline $\begin{array}{l}\text { Body } \\
\text { Diameter } \\
\text { Options }\end{array}$ & $3.25 \mathrm{~mm}$ & $\begin{array}{l}3.25 \mathrm{~mm}, \\
3.75 \mathrm{~mm}, \\
4 \mathrm{~mm}\end{array}$ & $\begin{array}{l}4 \mathrm{~mm} \\
5 \mathrm{~mm}\end{array}$ \\
\hline
\end{tabular}

Platform Switching. The concept of platform of platform switching was introduced by Lazzara and Porter (2006). They stated that platform switching could be beneficial in maintaining peri-implant marginal bone loss both mechanically and biologically. Placing a smaller diameter restorative component increased the distance between the abutment-associated inflammatory cell infiltrate and the marginal bone level, and thereby decreased the bone-resorptive effect.

Hermann et al. (1997) reported that 1 year after dental implants were restored with prosthetic components of matching diameter, there was crestal bone re-modeling around the coronal part of the implant and about $1.5-2 \mathrm{~mm}$ of vertical bone loss. Broggini et al. (2006) proposed that crestal bone loss might be due to biologic width reestablishment following chronic bacterial colonization and inflammation of the implant/abutment connection. Hermann et al. (2001) reported that additional bone resorption might be correlated to micromovements at the implant-abutment interface (IAI). Cappiello et al. (2008) evaluated the bone loss around switched implants with 
abutments $1 \mathrm{~mm}$ narrower than the platform compared to no platform switch. Results showed after 12 months of loading the platform switch implants had a mean vertical bone loss of $0.95 \mathrm{~mm}$ while the non-platform switched had $1.67 \mathrm{~mm}$. This data confirmed the role of the microgap between the implant and abutment in the remodeling of the periimplant crestal bone. It was concluded that platform switching reduced peri-implant crestal bone resorption and increased the long-term predictability of implant therapy. Canullo et al. (2010) examined the benefits of different mismatching diameter switching platforms. Eighty implants were divided according to the platform diameter in four groups: $3.8 \mathrm{~mm}$ (control), $4.3 \mathrm{~mm}$ (test group 1), $4.8 \mathrm{~mm}$ (test group 2) and $5.5 \mathrm{~mm}$ (test group 3), and all implants were connected to a 3.8-mm-diameter abutment. Over period of three years, it was demonstrated that there was an inverse correlation between the extent of mismatching. It was observed that marginal bone loss was significantly less and better maintained with increasing implant/abutment mismatching.

Provisionalization. Restorative and prosthetic techniques are helpful in treating papillary insufficiency and enhancing papilla formation. Jemt (1999) compared interimplant papillary formation by means of placing either a provisional resin crown or a healing abutment at the time of second stage surgery. It was concluded that the use of provisional crowns was able to guide the soft tissue into the inter-implant space faster than healing abutments alone.

The preparation of esthetically appealing and anatomically correct implantsupported provisional restorations facilitated fabrication of the final implant-supported crown (David 2008). According to the author, the provisional restoration was used to sculpt and manipulate the soft tissue and act as a blueprint or template for the final 
crown. It was recommended that the provisional restoration be placed several weeks before the final impression to allow for the maturation of the peri-implant tissues. By altering the subgingival contours and outline of the provisional restoration, the periimplant gingival tissue can be molded and manipulated. If the facial surface of the provisional is convex or overcontoured the subgingival contour may displace the soft tissue apically. Conversely, creating an undercontoured subgingival contour will facilitate the coronal migration of the soft tissue margin. To assist the migration of the papilla in an incisal direction, a convex subgingival interproximal contour should be created. This drives the papillary tissue toward the proximal surface of the adjacent tooth and moves it incisally. It should support the surrounding tissues without exerting excessive pressure. Excessive pressure will restrict the vascular supply to the papillary tissue and cause necrosis (Tortamano et al. 2010). When optimal peri-implant tissue contours and levels are achieved, an impression for fabrication of the final restoration can be performed.

Castellon et al. (2005) discussed the modalities for immediate provisionalization of single tooth implants. The authors divided the aesthetic aspects of immediate provisionalization into implant placement, abutment selection and preparation. The benefits of immediate provisionalization of single tooth implants include: 1) tooth replacement; 2) maintenance of the interdental space, 3) development of the gingival sulcus; 4) facilitating the final restoration; and 5) improved patient comfort and elimination of second-stage surgery.

Restorative Success. Belser et al. (2004) stated that anterior implant success is maintenance or re-establishment of a harmoniously scalloped soft tissue and natural contours. For anterior single tooth replacement in sites without tissue deficiencies 
predictable treatment outcomes, including esthetics, can be achieved because of tissue support provided by the osseous crest of adjacent teeth. An optimal esthetic implant restoration depends on 4 anatomic and surgical parameters: 1) submucosal positioning of the implant platform; 2) adequate 3-dimensional implant positioning; 3) long-term stability of esthetic and peri-implant soft tissue contours; and 4) symmetry of clinical crown volumes between the implant site and contralateral teeth. Kan et al. (2011) reported that the esthetic success of implants is influenced by a number of factors including proper three-dimensional implant positioning and angulation, as well as appropriate contouring of the abutment and provisional restoration and hard and soft tissue relationships and gingival biotype. Utilizing a team approach for attaining optimal tissue architecture using the should be the primary treatment plan objective.

A meticulous multidisciplinary approach to diagnosing, treatment planning and implementing the appropriate surgical and prosthodontic techniques are paramount in a predictable and esthetic outcome.

Soft Tissue Augmentation. According to Allen (2011) augmentation grafting around implants provides thicker soft tissue that reduces the risk of recession and helps block the "dark" show through of the implant. The graft should match the adjacent tissue color and enhance esthetics. Peri-implant soft tissue esthetics in maxillary single implants is dependent on the bony support, which allows for symmetrical facial gingival contours and papilla volume between a natural tooth and an implant restoration. A loss of facial or interproximal peri-implant tissue volume can result in compromised soft tissue architecture and periodontal health. Therefore, a sufficient amount of tissue is of great interest regarding a favorable esthetic outcome (Grunder et al. 2005). The use of soft 
tissue grafts has been introduced to manage and prevent undesirable results with maxillary anterior implants.

Connective Tissue Graft. Tissue augmentation with a connective tissue (CT) graft has proven successful in preserving soft tissue marginal position when performed in conjunction with implant placement or abutment connection (Leizy et al. 2005). Soft tissue grafts have been advocated to manage the mid-facial recession and maintain periimplant tissue levels and volume ameliorating the width and position of peri-implant tissues and creating interproximal papilla (Tarnow et al. 1996).

Kan et al. (2009) reported that biotype conversion by increasing the quality and quantity of the facial gingival tissue with a CT graft at time of implant placement was beneficial for facial gingival stability making tissues more resistant to recession. At a mean follow-up time of 2.15 years all patients exhibited a thick biotype. The mean overall facial gingival level change was a mean $+0.13 \mathrm{~mm}$. Thick tissue showed a gain of $+0.23 \mathrm{~mm}$ while thin tissue showed a gain of $+0.06 \mathrm{~mm}$.

Wiesner et al. (2010) evaluated the efficacy of connective tissue grafting simultaneously with implant placement with respect to augmenting peri-implant soft tissue thickness in twenty patients. Ten patients received connective tissue grafts (test group), while 10 patients received no graft (control group). One year results after loading revealed a mean tissue thickness of $3.2 \mathrm{~mm}$ in the test group vs. $1.9 \mathrm{~mm}$ for the control. Soft tissues at grafted sites were $1.3 \mathrm{~mm}$ thicker, and had significantly better pink esthetic scores $(\mathrm{p}<0.001)$

Chung et al. (2011) reported a case series involving immediate single tooth replacement using platform switching implants and a simultaneously placed subepithelial 
connective tissue graft. At the 1-year follow-up, a mean facial gingival level change of $0.05 \mathrm{~mm}$ was reported and $89 \%$ of the sites demonstrated papilla fill greater than $50 \%$.

Tsuda et al. (2011) evaluated peri-implant tissue response following connective tissue and bone grafting in conjunction with immediate single-tooth replacement in the esthetic zone. A mean facial gingival level change of $-0.05 \mathrm{~mm}$ was reported at 1-year examination. In addition, at $80 \%$ of the sites, more than $50 \%$ papilla fill was observed.

Acellular Dermal Matrix. Response to soft tissue surgery around implants is different from soft tissue response around teeth. Allen (2011) recommended minimally invasive soft tissue grafting procedures for implants using a tunnel approach. This technique, implementing either a connective tissue graft or acellular dermal matrix (ADM), improves the likelihood for increased wound stability, preservation of papillary tissues and maximizing graft success. ADM has been proven to be a safe and efficacious alternative to palatal autografts for soft tissue augmentation eliminating the need for an additional surgical site (Allen 2011).

In implant therapy, $\mathrm{ADM}$ was initially used at the second stage of implant surgery to augment the soft tissue. It was sutured like an FGG in an attempt to increase the width of keratinized tissue around the dental implants (Callan et al. 1998). Yan et al. (2006) compared the effectiveness of acellular dermal matrix (ADM) and free gingival graft (FGG) in increasing the width of keratinzed tissue around dental implants in the maxillary and mandibular anterior regions. The width of keratinized tissue increase was recorded initially and 6 months after surgery. The width of keratinized tissue increased significantly following both treatments. The gain of keratinized tissue was $7.8 \mathrm{~mm}$ for FGG and $2.4 \mathrm{~mm}$ for ADM. The net gain was $7.3 \mathrm{~mm}$ for FGG and $1.8 \mathrm{~mm}$ for ADM. 
The shrinkage rate was $32.4 \%$ for FGG and $82 \%$ for ADM.

Park et al. (2006) investigated the clinical efficacy of an acellular dermal matrix allograft to achieve increased peri-implant keratinized mucosa around implants. It is concluded that the acellular dermal matrix allograft could be applied as a grafting material to increase the width of peri-implant keratinized mucosa. The width of periimplant keratinized mucosa increased from a baseline mean of 0.8 to $3.2 \mathrm{~mm}$ at 3 months and $2.2 \mathrm{~mm}$ at 6 months.

Although allograft materials have not demonstrated results that surpass the connective tissue grafts, they can provide successful esthetic outcomes, are available in abundance, and lead to reduced postoperative discomfort and surgical time. 


\section{CHAPTER II}

\section{METHODS}

Study Design. Twenty-five patients were invited to participate in this randomized, controlled, blinded clinical trial. By random selection, using a coin toss, fourteen positive control patients were selected to receive a delayed placement lasergrooved implant collar (Laser-Lok, Birmingham, Alabama) with a simultaneous connective tissue graft. Eleven test patients were selected to receive a delayed placement laser-grooved implant collar (Laser-Lok, BioHorizons, Birmingham, Alabama) with a simultaneous acellular dermal matrix allograft. The laser-grooved surface is $1.8 \mathrm{~mm}$ in length and consists of 8 micron grooved channels that promote connective tissue attachment, prevent apical migration of epithelium, and promote bone attachment. The surface of the implant body was a roughened RBT surface. All implants were placed in the maxillary esthetic zone, from second premolar to second premolar. A fixture level impression taken at the time of implant placement was sent to the dental laboratory for fabrication of a composite provisional restoration. Each patient received a post-surgical regimen of $50 \mathrm{mg}$ doxycycline hyclate qd for 2 weeks, $375 \mathrm{mg}$ naproxen one tab q $12 \mathrm{~h}$, and Vicodin ES one tablet q4-6h prn pain.

At two months post-surgery, implants were uncovered and a temporary abutment and provisional restoration were placed. Approximately 2 months were utilized for tissue 
shaping and development of an esthetic emergence profile.

Around four months post-surgery, another fixture level impression was taken and sent to the laboratory for fabrication of a final crown restoration. The final crown examination was completed at approximately 6 months.

Primary outcome variables were implant interproximal bone loss, soft tissue thickness, and objective soft tissue esthetics evaluated using the Jemt Papilla Index (1997), the Pink Esthetic Score (Furhauser et al., 2005), papilla harmony and gingival recession. Objective tooth esthetics were evaluated using the White Esthetic Score (Belser et al., 2009). A subjective esthetic evaluation was performed by each patient using a Visual Analog Scale for the soft tissue, the tooth, and an overall esthetic appearance.

Inclusion criteria. Inclusion criteria were: 1) Patients with one or more missing teeth in the esthetic zone of the maxilla between $\# 4$ and $\# 13$ to be replaced by dental implants; 2) Each implant site should be bordered by two teeth; 3) Patients must be 18 years of age or greater; and 4) Informed consent must approved by University of Louisville Human Studies Committee.

Exclusion criteria. Exclusion criteria were: 1) Patients with uncontrolled diabetes, immune disease, or systemic disease that significantly affects the periodontium; 2) Previous head and neck radiation; 3) Patients who have been on IV bisphosphonates or oral bisphosphonates for $>3$ years; 4) Smoker $>1 / 2$ pack per day; 5) Patients who need prophylactic antibiotics prior to dental procedures; 6) Patients with allergy to any medication or material used in the study; 7) Chemotherapy in the previous 12 months; 8) Severe psychological problems; 9) Patients unable to sign the informed consent; 10) 
Pregnant subjects will be excluded due to risk of miscarriage; and 11) History of allergy to common dentifrice ingredients.

Post-surgical exclusion. Any patients excluded after surgery will be reported and accounted for. Post surgical exclusion criteria are as follows: 1) Implant failure; and 2) Unanticipated healing complications that will adversely affect treatment results.

Pre-surgical management. Each patient received a diagnostic work-up including standardized radiographs (periapicals [Appendix D]), study casts, clinical photographs, and a clinical examination of teeth adjacent to the edentulous sites. Pre-surgical preparation included detailed oral hygiene instructions. Baseline data was collected at initial exam.

Clinical Indices at the tooth/implant site. At baseline, indices were completed for teeth adjacent to the edentulous site. At 2, 4, 6, and 12 months the indices were completed at the implant site. Indices evaluated were: 1) Plaque index (Appendix A); 2) Gingival index (Appendix B); 3) Mobility (Appendix C); 4) Probing depth. Measured from gingival margin to apical penetration of the probe tip; 5) Keratinized tissue: Measured from the gingival margin to the mucogingival junction; 6) Bleeding on probing (BOP): Present or absent; 7) Radiographic examination: Stents were constructed using Regisil ${ }^{\circledR} \mathrm{PB}^{\mathrm{TM}}$ Plaster Bite Registration Paste and a Rinn-XCP on the patient model so that standardized radiographs could be taken at selected time intervals (Appendix D); and 8) Clinical photographs were taken at $1,2,4,6$, and 8-week post-op. If needed, an additional post-op picture was taken every two weeks until soft tissue closure was complete. Clinical photographs were then taken at the 4 and 6 month post-op and at the 12 month final. 


\section{Pre-surgical measurements at the tooth/implant site. Pre-surgical}

measurements included: 1) CEJ to osseous crest measured on the radiograph at baseline, 2, 4, and 6 months; 2) Periodontal form: Flat, scalloped, or pronounced scallop (Appendix E); 3) Periodontal biotype: Thick, moderate, or thin (Appendix F);

4) Tooth shape: Square, ovoid, or triangular; 5) Gingival scallop measured from the facial gingival margin to papillae tip; 6) Papilla harmony (Appendix G); and 7) Gingival margin harmony (Appendix H). 8) Gingival thickness

Surgical treatment. All pre-surgical measurements were taken and a preoperative radiograph was taken with a stent in place to document pre-surgical bone levels. Patients were then anesthetized with $2 \%$ xylocaine containing epinephrine in both $1: 100,000$ and 1:50,000 concentrations. Papilla preservation incisions were used with the ridge incision placed towards the palate. A full thickness mucoperiosteal flap was elevated on the buccal and palatal to expose the alveolar ridge. Measurements from osseous crest to adjacent CEJ and osseous scallop were taken with a periodontal probe(s). Either a connective tissue autograft or an acellular dermal matrix allograft was randomly selected, using a coin toss, for placement at the implant site. Both control and test sites received a Biohorizons Tapered Internal Implant RBT, Laser-Lok implants. Implants were centered mesio-distally between the adjacent teeth, aligned between the insical edge and the cingulum for canines and incisors, or with the central groove for premolars. After implant placement post-implant measurements were completed.

A fixture level impression was taken at the time of implant placement using a closed or open tray impression coping with heavy body impression material (Aquasil Ultra Heavy, Smart Wetting ${ }^{\circledR}$ Impression Material, Dentsply Caulk, Milford, DE) and 
light body impression material (Aquasil Ultra XLV Smart Wetting ${ }^{\circledR}$ Impression Material, Dentsply Caulk, Milford, DE). The impression was sent to ADL (Louisville, KY) where provisional crowns were fabricated. Flaps were replaced and sutured for primary closure with 5-0 Maxon ${ }^{\mathrm{TM}}$ sutures (Monofilament Polyglyconate, Covidien, Mansfield, MA). Following implant placement, standardized radiographs were obtained with the stent in place. Patients were given naproxen $375 \mathrm{mg}$ (Geneva Pharmaceuticals, Inc. Broomfield, $\mathrm{CO}$ ), one tab q12h, doxycycline hyclate $50 \mathrm{mg}$ (Warner Chilcott Inc. Morris Planes, New Jersey), 1 tab qd, and Vicodin $\mathrm{ES}^{\circledR}$ (Abbot Laboratories. North Chicago, Illinois) 1 tab q4-6h prn pain.

Surgical measurements. Implant site measurements included: 1) Osseous crest to adjacent CEJ measured with a periodontal probe at the mesial and distal of the implant site; 2) Osseous scallop: The vertical distance from the midfacial osseous crest to a periodontal probe positioned horizontally at the adjacent gingival margins; 3) Implant platform vertical distance from the facial, mesial and distal osseous margins; 4) Horizontal osseous crest thickness from the facial crest to the implant platform; 5) Subjective evaluation of implant placement in three dimensions (Appendix I); 6) Bone quality at implant placement (Appendix J); and 7) Clinical photographs.

Prosthetic treatment. The implants were uncovered at two months. Minimal incisions were utilized to expose the implant, and were located palatally and the tissue was pushed facially. Temporary abutments were placed on the implant and torqued to 30 Ncm. A composite (Radica ${ }^{\circledR}$, Dentsply Prosthetics, York, PA) provisional fabricated by the laboratory (ADL, Louisville, KY) was placed. Radica ${ }^{\circledR}$ was used to fabricate provisional crowns and bridges and Integrity ${ }^{\circledR}$ was used to modify the crown contours. 
Integrity $^{\circledR}$ (Dentsply Prosthetics, York, PA) is a chemically polymerized composite resin. A radiograph was taken with stent in place to evaluate hard tissue levels.

Every two weeks for 8 weeks, patients were seen to adjust the provisional to shape the gingival contours. The contours of the provisional influence the position of the soft tissue. Removing some of the convexity from the facial of the provisional allows the tissue to migrate coronally. Increasing the facial convexity of the provisional will drive the tissue apically. Adding material to the interproximal of the provisional adds support for the papillae. After all parameters were fulfilled, including patient satisfaction, a final impression was taken, and the lab fabricated a definitive restoration.

After the soft tissue margins were established, at approximately 4 months, a final impression was taken. The provisional abutment and crown were removed and attached to an implant analog. An impression was taken of the provisional and analog using Regisil $^{\circledR}$ (Dentsply Caulk, Milford, DE) in a small plastic cup. The provisional and the temporary abutment were removed from the Regisil ${ }^{\circledR}$ impression, and an impression coping was attached to the analog, which remained in the impression. DuraLay ${ }^{(\mathbb{B}}$ (Reliance, Worth, IL) acrylic was placed around the impression coping using a "salt and pepper" technique into the impression. The impression coping with attached DuraLay ${ }^{\circledR}$ was removed from the Regisil ${ }^{\circledR}$ impression and transferred to the implant in the mouth. The DuraLay ${ }^{\circledR}$ replicated the subgingival contour of the provisional, and therefore indirectly captured the subgingival emergence profile. An impression was taken using heavy body impression material (Aquasil Ultra Heavy, Smart Wetting ${ }^{\circledR}$ Impression Material, Dentsply Caulk, Milford, DE) and light body impression material. A shade was chosen by the patient using a Portrait $\mathrm{IPN}^{\circledR}$ shade guide (Dentsply Trubyte, York, PA) 
and sent to ADL along with the final impression and a photo of the area. Another radiograph was taken with stent in place to evaluate hard tissue levels.

When the final restoration returned from the lab, the patient was appointed and the crown was placed. The provisional and the temporary abutment were removed. All final crowns were screw retained restorations. The final restoration was placed and torqued to $30 \mathrm{Ncm}$. The screw access was covered with a cotton pellet and a high definition micro matrix composite restorative material (Esthet-X® HD, Dentsply Caulk, Milford, DE). Occlusion and contacts were checked.

Patients were then scheduled for the 6-month exam, which was about 2 months after the restoration, was placed. Standardized radiographs were taken with the stent in place to evaluate hard tissue parameters. Clinical photographs and the collection of final data including the Jemt papilla index (Appendix M), the Pink Esthetic Score (Appendix K), and the White Esthetic Score (Appendix L) were taken. Patients completed three questions on a Visual Analog Scale to assess patient subjective evaluation of esthetics (Appendix N).

Radiographic and clinical measurements for the implant at 2, 4, 6, and 12 months were taken. Radiographic and clinical measurements for implant included: 1) Location of interproximal contact mesial and distal: Ideal, incisal or apical; 2) Vertical length of interproximal contact mesial and distal: Short, normal, or long; 3) Osseous crest to contact; 4) Osseous crest to contact radiographic (6 month only); 5) Osseous crest to $\mathrm{CEJ}$; 6) Osseous crest to $\mathrm{CEJ}$ radiographic; 7) Facial recession; 8) Emergence (implant top to gingival margin) facial, mesial, distal; 9) Gingival scallop; 10) Papilla harmony (Appendix G); 11) Gingival margin harmony (Appendix H); and 12) Black triangle. 
Restoration Form. Restoration form included: 1) Contact location: Ideal, incisal, or apical; 2) Contact length: Normal, long, or short; 3) Restorative margin: Good, overhung, or overextended; and 4) Emergence profile: Good, overbulked, or undercontoured.

Measurement techniques. All probing measurements were taken using the University of North Carolina probe. A masked, calibrated examiner (Appendix N) performed the initial examination and all study measurements. Standardized periapical and vertical bitewing radiographs and measurements were taken at the 2, 4, and 6-month examinations.

Statistical Analysis. Means and standard deviations were calculated for all parameters. A paired t-test was used to evaluate the statistical significance of the differences between initial and final data. An unpaired t-test was used to evaluate statistical differences between the test and control groups. A sample size of 12 gave at least $80 \%$ statistical power to detect a difference of $0.4 \mathrm{~mm}$ soft tissue thickness both within and between groups. 


\section{CHAPTER III}

\section{RESULTS}

A total of 15 females and 10 males with a mean age of 52, ranging from 22 to 77 , were enrolled. The connective tissue (CT) group consisted of 4 maxillary central incisors, 1 maxillary canine and 9 maxillary premolars. The acellular dermal matrix (ADM) group consisted of 1 maxillary central incisor, 1 maxillary lateral incisor, 2 maxillary canines and 7 maxillary premolars. There were 2 smokers enrolled in the ADM group. Subjective assessment at the time of implant placement indicated that for the ADM group 9 implants were placed in Type 2 bone and 2 were placed in Type 3 bone; for the CT group 10 implants were placed in Type 2 bone and 4 were placed in Type 3 bone. Data from this study was derived from 11 patients completed by Dr. Thomas Peterson and 13 completed by Dr. Gretchen Wigand. Two patients were exited from the study from the ADM group. Both patients were exited due to failure of the implant to osseointegrate.

\section{Implant Positioning}

Implant Placement Data. At placement, the mean vertical distance from the implant platform to the osseous crest for CT cases was $0.1 \pm 0.3 \mathrm{~mm}$ on the mid-facial, $2.3 \pm 1.3 \mathrm{~mm}$ on the mesial, and $-2.3 \pm 1.2 \mathrm{~mm}$ on the distal (a negative sign indicates that the bone crest was coronal to the implant platform, Table 13). For ADM cases, the mean distance was $0.2 \pm 0.6 \mathrm{~mm}$ on the mid-facial, $-3.4 \pm 0.6 \mathrm{~mm}$ on the mesial, and -3.3 $\pm 0.7 \mathrm{~mm}$ on the distal. There was a statistically significant difference between groups on 
the mesial and distal of the vertical distances $(\mathrm{p}<0.05$, Table 13). The mean horizontal distance from the implant collar to the facial osseous crest was $1.6 \pm 1.0 \mathrm{~mm}$ for CT cases and $1.6 \pm 0.8 \mathrm{~mm}$ for $\mathrm{ADM}$ cases $(\mathrm{p}>0.05$, Table 13). The mean horizontal interproximal distance from tooth to implant for CT cases was $2.9 \pm 0.4 \mathrm{~mm}$ on the mesial and $2.9 \pm 0.5 \mathrm{~mm}$ on the distal (Table 13). For ADM, the distance was $2.8 \pm 0.4$ $\mathrm{mm}$ on the mesial and $3.1 \pm 0.5 \mathrm{~mm}$ on the distal (Table 13). There were no statistically significant differences between groups for any of these horizontal measurements $(\mathrm{p}>$ 0.05 , Table 13). The mean osseous scallop existing or created at the time of implant placement was $2.8 \pm 0.8 \mathrm{~mm}$ for the CT sites and $2.8 \pm 0.5 \mathrm{~mm}$ for the ADM sites $(\mathrm{p}>$ $0.05)$.

\section{Emergence Profile Data}

Implant Platform to Gingival Margin. The mean distance from the implant platform to gingival margin at 6 months for the CT group was $3.0 \pm 0.5 \mathrm{~mm}$ on the facial, $4.4 \pm 1.1 \mathrm{~mm}$ on the mesial, and $4.6 \pm 0.9 \mathrm{~mm}$ on the distal. The mean distance from the implant platform to gingival margin at 6 months for the ADM group was $3.2 \pm 0.8 \mathrm{~mm}$ on the facial, $4.9 \pm 0.9 \mathrm{~mm}$ on the mesial, and $4.7 \pm 0.9 \mathrm{~mm}$ on the distal. There were no statistically significant differences between groups for any of these vertical measurements $(\mathrm{p}>0.05$, Table 14).

\section{Critical Dimensions Related to Papilla Formation}

Osseous Crest to Contact Distance. At 6 months, the mean distance from adjacent tooth osseous crest to the contact for CT sites was $4.3 \pm 1.0 \mathrm{~mm}$ and $3.9 \pm 1.0 \mathrm{on}$ the mesial and distal, respectively, and $4.4 \pm 0.9$ and $3.8 \pm 1.1$ for the ADM sites (Table 
15). There were no statistically significant differences between groups for either mesial or distal measurements $(\mathrm{p}>0.05)$.

Implant to Tooth Distance. Mean implant to tooth distance for the CT group was $2.9 \pm 0.4 \mathrm{~mm}$ on the mesial and $2.9 \pm 0.5 \mathrm{~mm}$ on the distal (Table 15). Mean implant to tooth distance for the ADM was $2.8 \pm 0.4$ for the mesial and $3.1 \pm 0.5$ for the distal. There were no statistically significant differences between groups for either mesial or distal measurements $(\mathrm{p}>0.05$, Table 15$)$.

\section{Soft Tissue Thickness}

Thickness at the Crest and $5 \mathbf{~ m m}$ apical. The CT thickness at the crest was 2.4 \pm 0.8 at time 0 and increased to $2.8 \pm 0.6 \mathrm{~mm}$ at 4 months for a mean change of $0.4 \pm 0.7$ $\mathrm{mm}(\mathrm{p}<0.05$, Table 16$)$. The ADM thickness at the crest was $2.3 \pm 0.7$ at time 0 which increased to $2.9 \pm 0.9 \mathrm{~mm}$ at 4 months for a mean change of $0.6 \pm 1.2 \mathrm{~mm}(\mathrm{p}>0.05)$. The CT thickness $5 \mathrm{~mm}$ apical to crest was $2.3 \pm 1.1$ at time 0 and increased to $2.8 \pm 0.7$ at 4 months for a mean change of $0.5 \pm 1.1 \mathrm{~mm}(\mathrm{p}>0.05)$. The ADM thickness $5 \mathrm{~mm}$ apical to crest was $1.9 \pm 0.6$ at time 0 and increased to $2.7 \pm 0.8$ at 4 months for a mean change of $0.8 \pm 0.9 \mathrm{~mm}(\mathrm{p}<0.05)$. There were no statistically significant differences between groups at any time $(\mathrm{p}>0.05$, Table 16$)$.

\section{Measures of Recession and Papilla Fill}

Gingival Margin Harmony and Recession Data. The CT sites presented with a mean of $0.3 \pm 0.4 \mathrm{~mm}$ recession at the 4-month measurement with no change at 6 months ( $p>0.05$, Table 14). ADM cases presented with a mean of $0.7 \pm 0.8 \mathrm{~mm}$ recession at 4 months which decreased to $0.5 \pm 0.5 \mathrm{~mm}$ at 6 months for a mean change of $-0.2 \pm 0.5$ $\mathrm{mm}(\mathrm{p}>0.05)$. There were no statistically significant differences between CT and ADM 
groups ( $\mathrm{p}>0.05$, Table 14). Gingival margin harmony was achieved in $64 \%$ (9 of 14) of CT cases at 6 months and 45\% (5 of 11) of the ADM cases at 6 months (Table 17).

Black Triangle, Papilla Harmony, and Gingival Scallop Data. The mean black triangle size for the CT sites decreased on the mesial from 4 to 6 months from $2.4 \pm$ $1.4 \mathrm{~mm}$ to $1.3 \pm 0.9 \mathrm{~mm}$, for a mean change of $-1.1 \pm 1.0 \mathrm{~mm}(\mathrm{p}<0.05)$, and on the distal from $2.4 \pm 0.8 \mathrm{~mm}$ to $1.7 \pm 1.0 \mathrm{~mm}$ for a mean change of $-0.7 \pm 0.6(\mathrm{p}<0.05$, Table 14$)$. Both mesial and distal mean black triangle changes in CT group were statistically significant. The mean black triangle size for the ADM sites also decreased on the mesial from 4 to 6 months from $2.0 \pm 1.0 \mathrm{~mm}$ to $1.2 \pm 1.0 \mathrm{~mm}$, for a mean change of $0.8 \pm 0.5$ $\mathrm{mm}(\mathrm{p}<0.05)$, and on the distal from $2.3 \pm 0.8 \mathrm{~mm}$ to $1.5 \pm 1.0 \mathrm{~mm}$ for a mean change of $0.8 \pm 0.7(\mathrm{p}<0.05)$. Both the mesial and distal mean black triangle changes for ADM were statistically significant $(\mathrm{p}<0.05)$. Papilla harmony was achieved in $36 \%$ (5 of 14$)$ of cases in the CT group and 27\% ( 3 of 11) of cases in the ADM group (Table 17). The mean gingival scallop for the CT sites was $1.0 \pm 0.9 \mathrm{~mm}$ at 2 months and increased to 2.3 \pm 0.9 at 6 months for a gain of $1.4 \pm 1.0 \mathrm{~mm}(\mathrm{p}<0.05)$. The mean gingival scallop for the ADM sites was $1.2 \pm 1.1 \mathrm{~mm}$ at 2 months and increased to $2.5 \pm 0.8$ at 6 months for a gain of $1.3 \pm 1.0 \mathrm{~mm}(\mathrm{p}<0.05)$. There were no statistically significant differences between groups $(\mathrm{p}>0.05)$.

\section{Subjective and Objective Esthetic Assessments}

Objective Evaluation of Esthetic Success. The mean pink esthetic score (Furhauser et al. 2005) for the CT group was $11.6 \pm 1.5$, and $11.7 \pm 1.6$ for the ADM group ( $p>0.05$, Table 18). The Jemt papilla index (Jemt 1997) on the mesial was $2.0 \pm$ 0.5 for the CT group and $2.3 \pm 0.5$ for the ADM group ( $p>0.05$, Table 17). The Jemt 
papilla index on the distal was $2.0 \pm 0.5$ for the CT group and $2.0 \pm 0.6$ for the ADM group ( $\mathrm{p}>0.05$ ). Using the Jemt index, CT cases had $\geq 50 \%$ papilla present in $93 \%$ (26 of 28) of cases versus $100 \%$ (22 of 22) for ADM cases (Table 18). The mean white esthetic score (Belser et al. 2009) for the CT group was $8.2 \pm 1.3$, and $8.7 \pm 1.5$ for the ADM group (Table 18).

Patient Subjective Evaluation of Implant Esthetics. Patients were asked to evaluate tooth esthetics, gingival esthetics, and overall esthetics on a visual analog scale that measured $100 \mathrm{~mm}$ in length. Results for tooth esthetics was a mean score of $99.2 \pm$ 1.6 for CT cases and $98.5 \pm 2.2$ for ADM cases $(p>0.05$, Table 18). Gingival esthetics was a mean score of $97.6 \pm 4.5$ for CT cases and 98.3 \pm 2.6 for ADM cases $(p>0.05)$. Overall esthetics was a mean score of $99.4 \pm 1.3$ for CT cases and $98.5 \pm 2.1$ for ADM cases $(p>0.05)$

\section{Indicators of Peri-implant Tissue Health}

Clinical Indices. In both groups the plaque index, gingival index and bleeding on probing index had low mean values at 4 and 6 months. Mean plaque index for the CT group was $0.2 \pm 0.2$ at 4 months and at 6 months (Table 20). Mean plaque index for the ADM group was $0.2 \pm 0.2$ at 4 months and 6 months. There were no statistically significant differences between groups for mean plaque index scores $(p>0.05$, Table 20 ). Mean gingival index for the CT group was $0.2 \pm 0.2$ at 4 and 6 months (Table 20). Mean gingival index for the ADM group was $0.2 \pm 0.2$ at 4 months and at 6 months. There were no statistically significant differences between groups for mean gingival index scores ( $p>$ 0.05 , Table 20). There was no change observed between bleeding on probing between 4 and 6 months for both CT and ADM groups (Table 20). There was an increase in the 
mean keratinized tissue for the CT group from $4.5 \pm 1.2 \mathrm{~mm}$ at 4 months to $4.7 \pm 0.9 \mathrm{~mm}$ at 6 months for a mean gain of $0.2 \pm 0.6 \mathrm{~mm}(\mathrm{p}>0.05)$. There was a slight decrease in the mean keratinized tissue for the ADM group from $5.0 \pm 0.8 \mathrm{~mm}$ at 4 months to $4.8 \pm$ $1.1 \mathrm{~mm}$ at 6 months for a mean loss of $-0.2 \pm 0.6 \mathrm{~mm}(\mathrm{p}>0.05$, Table 19). There were no statistically significant differences from 4 to 6 month values or between groups for either of these variables $(\mathrm{p}>0.05)$.

Probing Depth. The CT sites had a mean probing depth of $1.9 \pm 0.2$ at 4 months and at 6 months (Table 19). The ADM sites had a mean probing depth of $2.0 \pm 0.5$ at 4 months which decreased to $1.9 \pm 0.5 \mathrm{~mm}$ at 6 months for a mean change of $-0.1 \pm 0.3$ $\mathrm{mm}(\mathrm{p}>0.05)$. There were no statistically significant differences between groups at any time $(\mathrm{p}>0.05$, Table 20).

Osseous Crest to CEJ. Between 0 and 6 months, there was $\leq 0.5 \mathrm{~mm}$ of mean bone loss from the adjacent tooth CEJ to the osseous crest on the mesial and distal for both groups. There was no change on the mesial but there was a $-0.1 \pm 0.7 \mathrm{~mm}$ mean loss for the distal in the CT group ( $p>0.05$, Table 21); and $-0.3 \pm 0.6$ mm of mean bone loss on the mesial and $-0.3 \pm 0.8 \mathrm{~mm}$ mean loss for the distal in the ADM group ( $\mathrm{p}>0.05)$. There were no statistically significant differences between groups ( $p>0.05$, Table 21).

Implant Platform to Mesial and Distal Osseous Crest. Implant platform to mesial osseous crest radiographically for the CT group was a mean of $0.0 \pm 0.0$ at time 0 and increased to $-0.4 \pm 0.4$ at 6 months for a mean change of $0.4 \pm 0.4(p<0.05$, Table 22). Implant platform to distal osseous crest radiographically for the CT group was a mean of $0.0 \pm 0.0$ at time 0 and increased to $0.2 \pm 0.3$ at time 6 for a mean change of -0.2 $\pm 0.3(\mathrm{p}<0.05)$. Implant platform to mesial osseous crest radiographically for the ADM 
group was a mean of $0.0 \pm 0.0$ at time 0 and increased to $0.3 \pm 0.5$ at 6 months for a mean change of $0.3 \pm 0.5(\mathrm{p}<0.05)$. Implant platform to distal osseous crest radiographically for the ADM group was a mean of $0.0 \pm 0.0$ at time 0 and changed to $0.2 \pm 0.4$ at time 6 for a mean change of $0.2 \pm 0.4(\mathrm{p}>0.05)$. There were no statistically significant differences between groups ( $p>0.05$, Table 22). 
Table 13

Implant Placement Data

Mean \pm sd in mm

\begin{tabular}{|llcc|}
\hline & Facial & Mesial & Distal \\
\hline Acellular Dermal Matrix & & & \\
Implant - Osseous Vertical & $0.2 \pm 0.6$ & $-3.4 \pm 0.6$ & $-3.3 \pm 0.7$ \\
Implant - Facial Bone Horiz & $1.6 \pm 0.8$ & & \\
Implant - Tooth Mesial-Distal & & $2.8 \pm 0.4$ & $3.1 \pm 0.5$ \\
\hline Connective Tissue & & & \\
Implant - Osseous Vertical & $0.1 \pm 0.3$ & $-2.3 \pm 1.3+$ & $-2.3 \pm 1.2+$ \\
Implant - Facial Bone Horiz & $1.6 \pm 1.0$ & & \\
Implant - Tooth Mesial-Distal & & $2.9 \pm 0.4$ & $2.9 \pm 0.5$ \\
\hline
\end{tabular}

$+=\mathrm{p}<0.05$ between ADM and CT groups 
Table 14

Soft Tissue Dimensions

Mean \pm sd in $\mathbf{m m}$

\begin{tabular}{|lccc|}
\hline & Time 4 & Time 6 & Change \\
\hline Acellular Dermal Matrix & & & \\
Implant- Gingival Margin M & $6.0 \pm 0.6$ & $4.9 \pm 0.9$ & $-1.1 \pm 1.1^{*}$ \\
Implant- Gingival Margin D & $5.6 \pm 1.0$ & $4.7 \pm 0.9$ & $-0.9 \pm 1.2^{*}$ \\
Implant- Gingival Margin F & $3.3 \pm 0.9$ & $3.2 \pm 0.8$ & $-0.1 \pm 0.6$ \\
Recession Facial & $0.7 \pm 0.8$ & $0.5 \pm 0.5$ & $-0.2 \pm 0.5$ \\
Black Triangle Mesial & $2.0 \pm 1.0$ & $1.2 \pm 1.0$ & $0.8 \pm 0.5^{*}$ \\
Black Triangle Distal & $2.3 \pm 0.8$ & $1.5 \pm 1.0$ & $0.8 \pm 0.7^{*}$ \\
\hline Connective Tissue & & & \\
Implant- Gingival Margin M & $5.9 \pm 1.1$ & $4.4 \pm 1.1$ & $-1.5 \pm 1.1^{*}$ \\
Implant- Gingival Margin D & $5.5 \pm 1.0$ & $4.6 \pm 0.9$ & $-0.9 \pm 1.5^{*}$ \\
Implant- Gingival Margin F & $3.6 \pm 0.9$ & $3.0 \pm 0.5$ & $-0.6 \pm 1.0$ \\
Recession Facial & $0.3 \pm 0.4$ & $0.3 \pm 0.4$ & $0.0 \pm 0.2$ \\
Black Triangle Mesial & $2.4 \pm 1.4$ & $1.3 \pm 0.9$ & $1.1 \pm 1.0^{*}$ \\
Black Triangle Distal & $2.4 \pm 0.8$ & $1.7 \pm 1.0$ & $0.7 \pm 0.6^{*}$ \\
\hline
\end{tabular}

$*=p<0.05$ between time 4 and time 6 
Table 15

Dimensions Related to Papilla Formation

Mean $\pm s d$ in $\mathrm{mm}$

\begin{tabular}{|lc|}
\hline & Time 6 \\
\hline \hline Acellular Dermal Matrix & \\
\hline Mesial & $4.4 \pm 0.9$ \\
Osseous Crest - Contact & $2.8 \pm 0.4$ \\
Implant - Tooth & \\
Distal & $3.8 \pm 1.1$ \\
Osseous Crest - Contact & $3.1 \pm 0.5$ \\
Implant - Tooth & \\
\hline Connective Tissue & \\
Mesial & $4.3 \pm 1.0$ \\
Osseous Crest - Contact & $2.9 \pm 0.4$ \\
Implant - Tooth & \\
Distal & $3.9 \pm 1.0$ \\
Osseous Crest - Contact & $2.9 \pm 0.5$ \\
Implant - Tooth & \\
\hline
\end{tabular}


Table 16

Soft Tissue Thickness at the Mid-Implant Crest and $5 \mathbf{~ m m}$ Apical

Mean \pm sd in $\mathbf{m m}$

\begin{tabular}{|lccc|}
\hline & Time 0 & Time 4 & Change \\
\hline Acellular Dermal Matrix & & & \\
Thickness at Crest & $2.3 \pm 0.7$ & $2.9 \pm 0.9$ & $0.6 \pm 1.2$ \\
Thickness 5 mm apical & $1.9 \pm 0.6$ & $2.7 \pm 0.8$ & $0.8 \pm 0.9^{*}$ \\
\hline Connective Tissue & & & \\
Thickness at Crest & $2.4 \pm 0.8$ & $2.8 \pm 0.6$ & $0.4 \pm 0.7^{*}$ \\
Thickness 5 mm apical & $2.3 \pm 1.1$ & $2.8 \pm 0.7$ & $0.5 \pm 1.1$ \\
\hline
\end{tabular}

${ }^{*}=\mathrm{p}<0.05$ between time 0 and time 4 
Table 17

Frequency of Papilla and Gingival Margin Harmony

\begin{tabular}{|lcc|}
\hline & ADM & CT \\
\hline Papilla Harmony & $27 \%(3$ of 11$)$ & $36 \%(5$ of 14$)$ \\
Gingival Margin Harmony & $45 \%(5$ of 11$)$ & $64 \%(9$ of 14$)$ \\
\hline
\end{tabular}


Table 18

Objective and Subjective Evaluation of Implant Esthetics

\begin{tabular}{|lcc|}
\hline & ADM & CT \\
\hline Pink Esthetic Score & & \\
White Esthetic Score & $11.7 \pm 1.6$ & $11.6 \pm 1.5$ \\
Jemt Papilla Index Mesial & $8.7 \pm 1.5$ & $8.2 \pm 1.3$ \\
Jemt Papilla Index Distal & $2.3 \pm 0.5$ & $2.0 \pm 0.5$ \\
Visual Analog Tooth & $2.0 \pm 0.6$ & $2.0 \pm 0.5$ \\
Visual Analog Gingiva & $98.5 \pm 2.2$ & $99.2 \pm 1.6$ \\
Visual Analog Overall & $98.3 \pm 2.6$ & $97.6 \pm 4.5$ \\
& $98.5 \pm 2.1$ & $99.4 \pm 1.3$ \\
\hline
\end{tabular}


Table 19

Jemt Papilla Index Stratified by Amount of Vertical Fill

\begin{tabular}{|lccc|}
\hline & Jemt Score & ADM & CT \\
\hline \hline Complete & 3 or 4 & $27 \%(6$ of 22$)$ & $14 \%(4$ of 28$)$ \\
$\geq \mathbf{5 0 \% \text { Papilla }}$ & 2,3 or 4 & $100 \%(22$ of 22$)$ & $93 \%(26$ of 28$)$ \\
$\leq \mathbf{5 0 \% \text { Papilla }}$ & 0 or 1 & $9 \%(2$ of 22$)$ & $7 \%(2$ of 28$)$ \\
\hline
\end{tabular}


Table 20

\section{Clinical Indices}

Mean \pm sd in $\mathbf{m m}$

\begin{tabular}{|lccc|}
\hline & Visit 4 & Visit 6 & Change \\
\hline \hline Acellular Dermal Matrix & & & \\
\hline Plaque Index & $0.2 \pm 0.2$ & $0.2 \pm 0.2$ & $0.0 \pm 0.2$ \\
Gingival Index & $0.2 \pm 0.2$ & $0.2 \pm 0.2$ & $0.0 \pm 0.3$ \\
Bleeding on Probing & $0.1 \pm 0.1$ & $0.1 \pm 0.1$ & $0.0 \pm 0.1$ \\
Keratinized Tissue & $5.0 \pm 0.8$ & $4.8 \pm 1.1$ & $-0.2 \pm 0.6$ \\
Mean Probing Depth & $2.0 \pm 0.5$ & $1.9 \pm 0.5$ & $-0.1 \pm 0.3$ \\
\hline Connective Tissue & & & \\
Plaque Index & $0.2 \pm 0.2$ & $0.2 \pm 0.2$ & $0.0 \pm 0.2$ \\
Gingival Index & $0.2 \pm 0.2$ & $0.2 \pm 0.2$ & $0.0 \pm 0.2$ \\
Bleeding on Probing & $0.1 \pm 0.1$ & $0.1 \pm 0.1$ & $0.0 \pm 0.1$ \\
Keratinized Tissue & $4.5 \pm 1.2$ & $4.7 \pm 0.9$ & $0.2 \pm 0.6$ \\
Mean Probing Depth & $1.9 \pm 0.2$ & $1.9 \pm 0.3$ & $0.0 \pm 0.3$ \\
\hline
\end{tabular}


Table 21

Adjacent Tooth Bone Loss

Mean $\pm s d$ in mm

\begin{tabular}{|c|c|c|c|}
\hline & Time 0 & Time 6 & Change \\
\hline \multicolumn{4}{|c|}{ Osseous Crest - CEJ } \\
\hline \multicolumn{4}{|c|}{ Radiographic } \\
\hline \multicolumn{4}{|c|}{ Acellular Dermal Matrix } \\
\hline Mesial & $2.4 \pm 1.1$ & $2.7 \pm 1.2$ & $-0.3 \pm 0.6$ \\
\hline Distal & $2.3 \pm 1.1$ & $2.6 \pm 1.1$ & $-0.3 \pm 0.8$ \\
\hline \multicolumn{4}{|c|}{ Connective Tissue } \\
\hline Mesial & $2.5 \pm 0.7$ & $2.5 \pm 0.5$ & $0.0 \pm 0.7$ \\
\hline Distal & $2.1 \pm 0.9$ & $2.2 \pm 0.6$ & $-0.1 \pm 0.7$ \\
\hline
\end{tabular}


Table 22

Implant Platform to Mesial and Distal Osseous Crest

Mean $\pm s d$ in $\mathbf{m m}$

\begin{tabular}{|llll|}
\hline & Time 0 & Time 6 & Change 0-6 \\
\hline Acellular Dermal Matrix & & & \\
\hline Implant to Oss Crest M & $0.0 \pm 0.0$ & $-0.3 \pm 0.5$ & $-0.3 \pm 0.5^{*}$ \\
Implant to Oss Crest D & $0.0 \pm 0.0$ & $-0.2 \pm 0.4$ & $-0.2 \pm 0.4$ \\
\hline Connective Tissue & & & \\
\hline Implant to Oss Crest M & $0.0 \pm 0.0$ & $-0.4 \pm 0.4$ & $-0.4 \pm 0.4^{*}$ \\
Implant to Oss Crest D & $0.0 \pm 0.0$ & $-0.2 \pm 0.3$ & $-0.2 \pm 0.3^{*}$ \\
\hline \hline Time 2 & Time 6 & Change 2-6 \\
\hline Acellular Dermal Matrix & $-0.1 \pm 0.3$ & $-0.3 \pm 0.5$ & $-0.2 \pm 0.4$ \\
Implant to Oss Crest M & $-0.2 \pm 0.5$ & $-0.2 \pm 0.4$ & $0.0 \pm 0.3$ \\
Implant to Oss Crest D & & & \\
\hline Connective Tissue & $-0.1 \pm 0.5$ & $-0.4 \pm 0.4$ & $-0.3 \pm 0.7$ \\
\hline Implant to Oss Crest M & $-0.1 \pm 0.5$ & $-0.2 \pm 0.3$ & $-0.1 \pm 0.6$ \\
\hline Implant to Oss Crest D & & & \\
\hline
\end{tabular}

$*=p<0.05$ between time 0 and time 6 


\section{CHAPTER IV}

\section{DISCUSSION}

The aim of this randomized, controlled, blinded clinical trial was to compare the hard and soft tissue response following either a connective tissue (CT) autograft or an acellular dermal matrix (ADM) allograft placed simultaneously with a laser-grooved implant into a single edentulous site in the maxillary anterior esthetic zone from second premolar to second premolar. Healing was similar for both the CT and ADM grafted sites.

Implant Placement. The objectives of implant placement were established mesio-distally, facially-lingually and apico-coronally. Implants were centered mesiodistally between the adjacent teeth with at least $1.5 \mathrm{~mm}$ between the implant body and the tooth (Tarnow et al. 2000). Facially-lingually the implant was aligned between the adjacent incisal edge and cingulum for incisors and canines, or with the central groove for premolars with at least $1 \mathrm{~mm}$ of bone facial to the implant body (Spray et al. 2000, Buser et al. 2004, Evans and Chen et al. 2008). The osseous crest was scalloped in order to provide sufficient emergence to allow a gradual transition from the implant platform to the facial osseous crest. The implant platform should be approximately 2 to $3 \mathrm{~mm}$ apical to the adjacent gingival margins (Saadoun et al. 1997, Buser et al. 2004). Mean placement data indicates that these objectives were achieved (Table 13). 
Implant Bone Loss. In this study, a Bio-Horizons Laser-Lok implant with a 1.8 $\mathrm{mm}$ collar with $8 \mu \mathrm{m}$ grooves to prevent apical migration of the epithelium and to promote both connective tissue and osseous attachment, was placed. At 6 months, the mean radiographic interproximal osseous position on the laser-grooved implants was approximately $0.3 \mathrm{~mm}$ apical to the interproximal platform in the CT group and $0.3 \mathrm{~mm}$ in the ADM group (Table 22). The majority of bone loss occurred between time 0 and time 6 (abutment connection and provisional placement).

Tissue Thickness. Kim et al. (2011) showed that sites with thicker gingival biotypes exhibited statistically significantly smaller changes in facial gingival levels than sites with thinner gingival biotypes at 1 year after placement. Kim et al. (2009) found more recession in patients with deficient keratinized tissue. Allen (2011) reported soft tissue augmentation around implants provides thicker tissue, which reduces the risk of recession. In the present study tissue thickness at crown placement was similar for both CT and ADM groups (Table 16). Tissue thickness at the crest was $2.8 \mathrm{~mm}$ and $2.9 \mathrm{~mm}$ for CT and ADM groups respectively. Tissue thickness $5 \mathrm{~mm}$ apical to crest revealed a thickness of $2.8 \mathrm{~mm}$ for $\mathrm{CT}$ and $2.7 \mathrm{~mm}$ for ADM. However, the change in tissue thickness from implant placement to crown placement was greater for sites receiving an ADM allograft. For the ADM group, the change in thickness at the crest was $0.6 \pm 1.2$ $\mathrm{mm}$, while the CT group had a change of $0.4 \pm 0.7 \mathrm{~mm}(\mathrm{p}<0.05) .5 \mathrm{~mm}$ apical to the crest, the ADM group exhibited a change of $0.8 \pm 0.9 \mathrm{~mm}(\mathrm{p}<0.05)$, while the CT thickness increased by only $0.5 \pm 1.1 \mathrm{~mm}$. Although these differences between groups were not statistically significant, the greater change noted in the ADM group may be clinically significant (Table 16). 
Recession. At 6 months the mean recession relative to the adjacent gingival margins was $0.3 \mathrm{~mm}$ for the $\mathrm{CT}$ group and $0.5 \mathrm{~mm}$ for the ADM group (Table 14). This is in agreement with previous studies published, which report up to $1 \mathrm{~mm}$ loss during the first year. Several factors can affect the amount of recession around dental implants: implant placement, facial bone thickness, tissue biotype amount of keratinized tissue and periodontal form. To achieving proper implant placement, approximately $2 \mathrm{~mm}$ of facial bone thickness should be present (Buser et al. 2004, Grunder et al. 2005). Mean facial bone thickness achieved in this study was $1.6 \mathrm{~mm}$ for both the CT and ADM groups. In this study biotype was subjectively rated as thick, moderate or thin (Kan et al. 2003, Zigdon \& Machtei 2008). The CT group had 1 thin and 13 moderate sites, while the ADM group had 10 moderate sites and 1 thick site. The width of the keratinized tissue is another factor that may influence facial recession (Kim et al. 2009, Zigdon \& Machtei 2008). At 6 months, the CT sites had a mean of $4.7 \mathrm{~mm}$ of keratinized tissue and the ADM had $4.8 \mathrm{~mm}$. For both CT and ADM groups, the mean facial bone thickness, tissue biotype and width of keratinized tissue were similar, which may have contributed to the similar amount of facial recession for both treatment groups.

In the current study, facial recession was assessed relative to the gingival margins on adjacent teeth. This method has been utilized in previous studies (Kan et al. 2003). The gingival margin harmony, or appropriate margin position relative to the adjacent teeth was achieved $64 \%$ of the time for the CT group and $45 \%$ of the time for the ADM group (Table 17). The soft tissue margin can also be assessed relative to the incisal edge, which provides a better assessment of marginal stability and change rather than actual recession (Gotfredsen 2004, Cooper et al. 2007). "True" recession is not an objective, 
direct measurement on an implant since it does not have a CEJ. The best measure may be relative to adjacent gingival margins. However, this assessment can be compromised when adjacent margins are in a receded position. In this case gingival margin harmony is the best indicator of the appropriate gingival margin position.

Papilla Formation. The presence of a papilla that completely fills a natural, normally sized interproximal space apical to a properly sized and located contact area is an important esthetic outcome. Papilla fill, however, can be achieved by decreasing the vertical height of the embrasure through the use of a long contact area. Thus papilla esthetics are best assessed using the dual measures of papilla fill and papilla harmony. The papilla height should be harmonious with the papillae on adjacent teeth. In this study papilla fill was assessed by measuring the "black triangle" or the space between the papilla tip and the base of the contact, the Jemt score (Jemt 1997), and by evaluating papilla harmony. The CT group had a Jemt score of $2.0 \pm 0.5 \mathrm{~mm}$ on the mesial and 2.0 $\pm 0.5 \mathrm{~mm}$ on the distal, while the ADM group had a Jemt score of $2.3 \pm 0.5 \mathrm{~mm}$ on the mesial and $2.0 \pm 0.6 \mathrm{~mm}$ on the distal $(\mathrm{p}>0.05$, Table 18). The mean black triangle size for the CT sites decreased on the mesial from 4 to 6 months from $2.4 \pm 1.4 \mathrm{~mm}$ to $1.3 \pm$ $0.9 \mathrm{~mm}$, for a mean change of $1.1 \pm 1.0 \mathrm{~mm}(\mathrm{p}<0.05)$, and on the distal from $2.4 \pm 0.8$ $\mathrm{mm}$ to $1.7 \pm 1.0 \mathrm{~mm}$ for a mean change of $0.7 \pm 0.6(\mathrm{p}<0.05$, Table 14$)$. Both mesial and distal mean papilla changes in CT group were statistically significant. The mean black triangle size for the ADM sites also decreased on the mesial from 4 to 6 months from $2.0 \pm 1.0 \mathrm{~mm}$ to $1.2 \pm 1.0 \mathrm{~mm}$, for a mean change of $0.8 \pm 0.5 \mathrm{~mm}$, and on the distal from $2.3 \pm 0.8 \mathrm{~mm}$ to $1.5 \pm 1.0 \mathrm{~mm}$ for a mean change of $0.8 \pm 0.7$. Both the mesial and distal mean papilla changes for ADM was statistically significant $(\mathrm{p}<0.05)$. 
The interproximal bone level on the tooth adjacent to the implant is another indicator of the potential for papilla fill. Thus the CEJ to osseous crest distance can be objectively measured. Previous studies have established that an osseous crest to contact distance of about $5 \mathrm{~mm}$ is a good predictor that papilla fill will be achieved between an implant and a tooth (Grunder 2000, Choquet et al. 2001, Tarnow et al. 2003, Gastaldo et al. 2004). Other variables can affect the existence and dimension of the papilla, which is a three dimensional structure. Both the vertical and the horizontal distance from implant to tooth must also be considered. Previous studies have shown that a horizontal distance of about $3 \mathrm{~mm}$ favors the best papilla result while greater or lesser distances may compromise papilla formation (Gastaldo et al. 2004, Lops et al. 2008, Romeo et al. 2008, Tarnow et al. 2000, Buser et al. 2004, Grunder et al. 2005). In this study the mean osseous crest to CEJ distance on adjacent teeth was between 2.2 and $2.5 \mathrm{~mm}$ for the CT group and between 2.6 and $2.7 \mathrm{~mm}$ for the ADM group at time 6 (Table 21). A distance of 1 to $2 \mathrm{~mm}$ would have been preferred, indicating no interproximal bone loss.

The osseous crest to contact distance (Table 15) for both the CT and ADM groups ranged between 3.9 and $4.4 \mathrm{~mm}$, which is less than the $5.0 \mathrm{~mm}$ necessary to gain complete papilla fill (Choquet et al. 2001). The horizontal distance from tooth to implant was approximately $3 \mathrm{~mm}$ for both groups (Table 13). Taking into consideration both these vertical and horizontal distances, "black triangles" resulted, ranging between 1.3 and $1.7 \mathrm{~mm}$ for CT sites and 1.2 to $1.5 \mathrm{~mm}$ at time 6 . This corresponded with papilla harmony of $36 \%$ at $\mathrm{CT}$ sites and $27 \%$ at ADM sites (Table 17). Improved papilla fill at 1 or more years after crown insertion has been demonstrated in previous studies (Jemt 1997, Schropp et al. 2008, Cardaropoli et al. 2006). In this study $\geq 50 \%$ papilla fill was 
achieved in $93 \%$ of the CT sites compared to $100 \%$ in the ADM sites. These results are in agreement with previous reports of papilla fill at the time of crown insertion (Jemt 1999, Lee et al. 2012).

The Pink Esthetic Score (PES), an objective index of soft tissue esthetics evaluating seven distinct soft tissue parameters: presence or absence of mesial and distal papilla, gingival margin, soft tissue contour, color, and texture, by a dental professional, with a score of 0 (worst) and of 14 (best), and each of seven categories receiving a score of 0,1 or 2 (Furhauser et al. 2005). In this study, the results of the PES were $11.6 \pm 1.5$ for the CT group and $11.7 \pm 1.6$ for the ADM group (Table 18). The White Esthetic Score (WES), specifically focuses on the implant restoration itself and objectively evaluates five parameters: tooth form, volume, color, texture, and translucency, by a dental professional, with a score of 0 (worst) and 10 (best), with each of the five categories receiving a score of 0,1 , or 2 (Belser et al. 2009). In this present study, the results of the WES were $8.2 \pm 1.3$ for the CT group and $8.7 \pm 1.5$ for the ADM group (Table 18). A visual analog scale was also used in this study as a subjective assessment, to determine patient satisfaction with the tooth alone, the gingiva alone and the overall tooth plus gingival appearance. Both, groups received high scores for all categories. Visual analog tooth was $99.2 \pm 1.6$ for the CT group and $9852 \pm 2.2$ for the ADM group (Table 18). Visual analog gingival was $97.6 \pm 4.5$ for the CT group and $98.3 \pm 2.6$ for the ADM group. Visual analog for overall appearance was $99.4 \pm 1.3$ for the CT group and $98.5 \pm$ 2.1 for the ADM group (Table 18). 


\section{CHAPTER V CONCLUSIONS}

Within the limitations of this study design the following conclusions were reached:

1) Both the acellular dermal matrix and the connective tissue groups had a similar increase in soft tissue thickness of about $0.5 \mathrm{~mm}$.

2) Objective and subjective esthetic scores were similar for acellular dermal matrix and connective tissue groups.

3) Bone loss after provisional placement was minimal and less than $0.4 \mathrm{~mm}$ for both groups. 
Figure 2. a) ADM Buccal Pre-op;

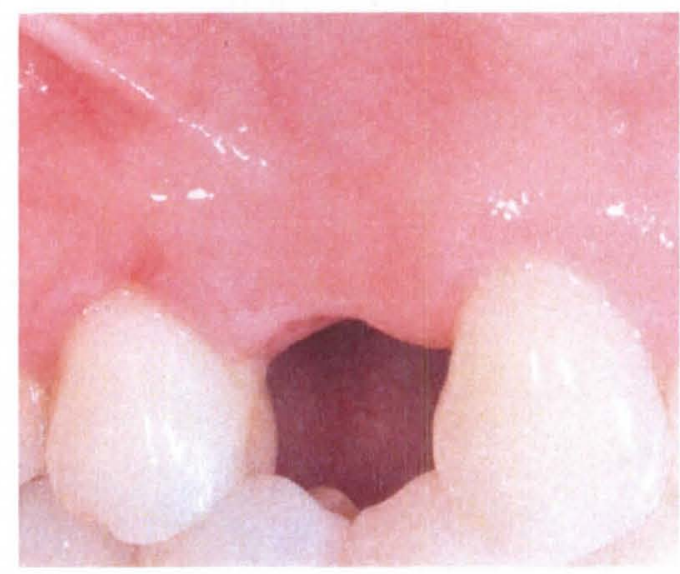

Figure 2. c) ADM Buccal Post-op;

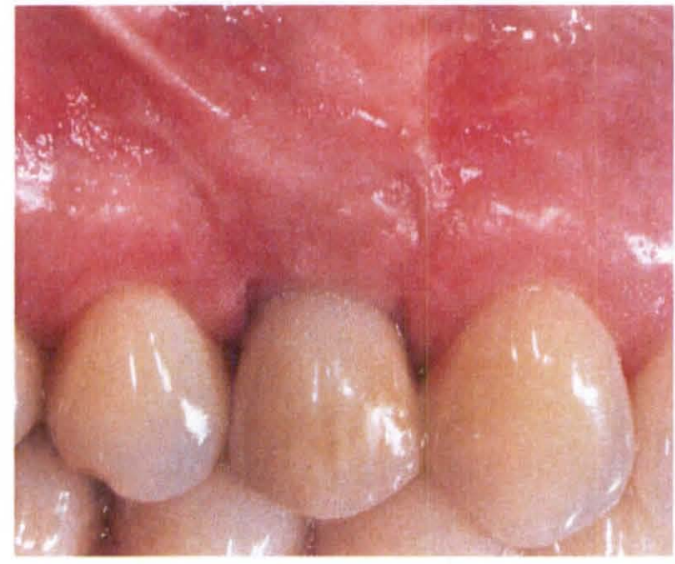

b) ADM Occlusal Pre-op

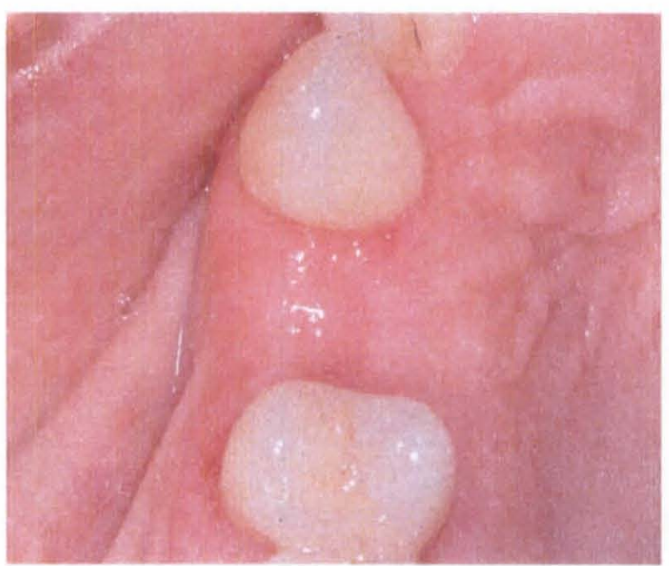

d) ADM Occlusal Post-op

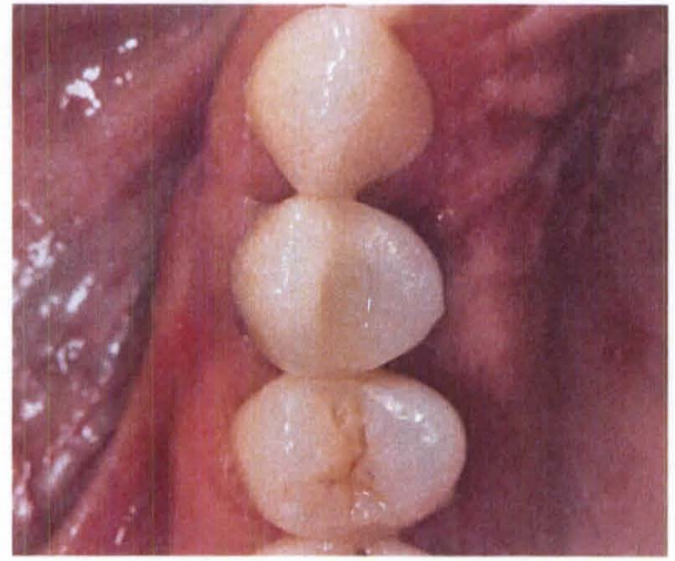


Figure 3. a) CT Buccal Pre-op;

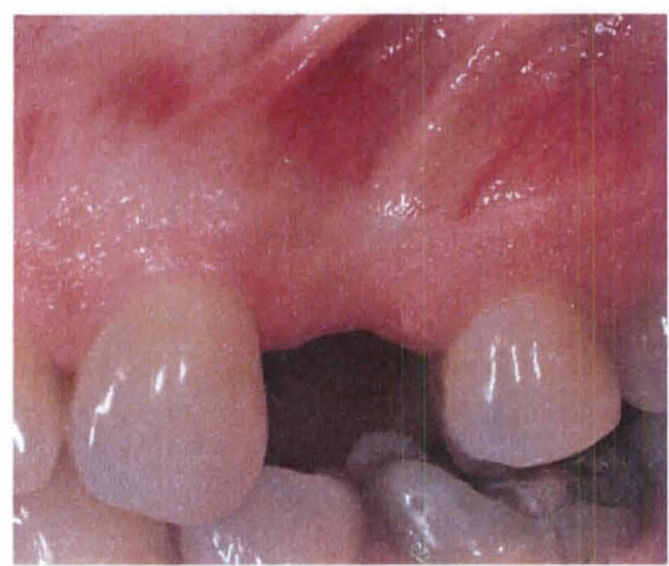

Figure 3. c) CT Buccal Post-op;

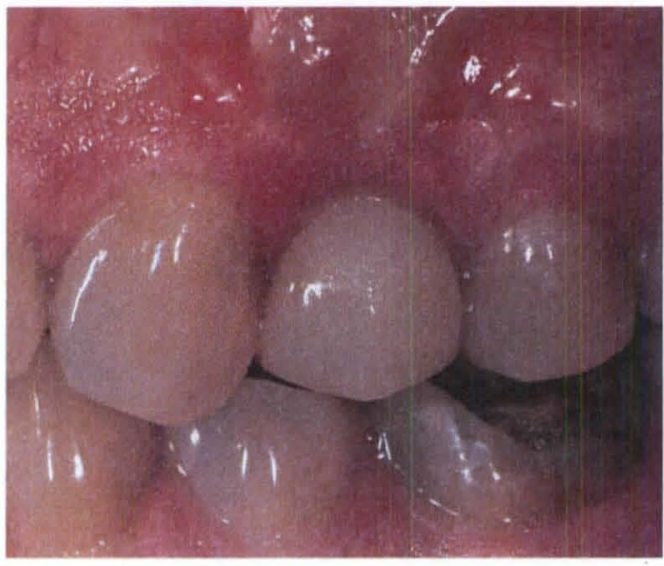

b) CT Occlusal Pre-op

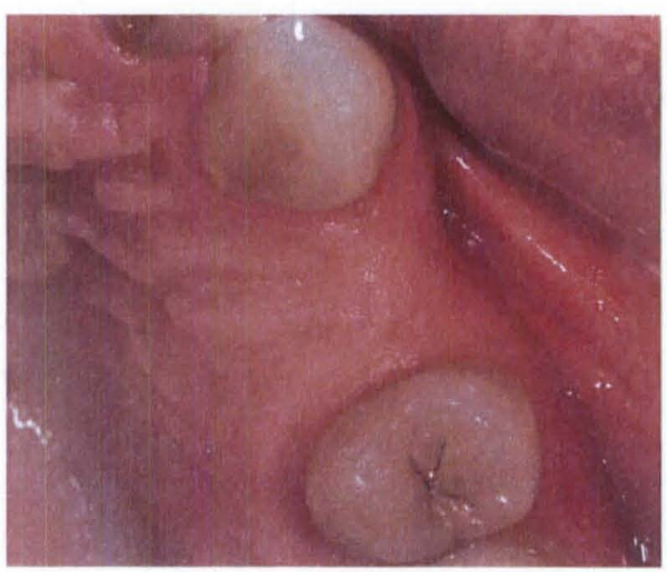

d) CT Occlusal Post-op

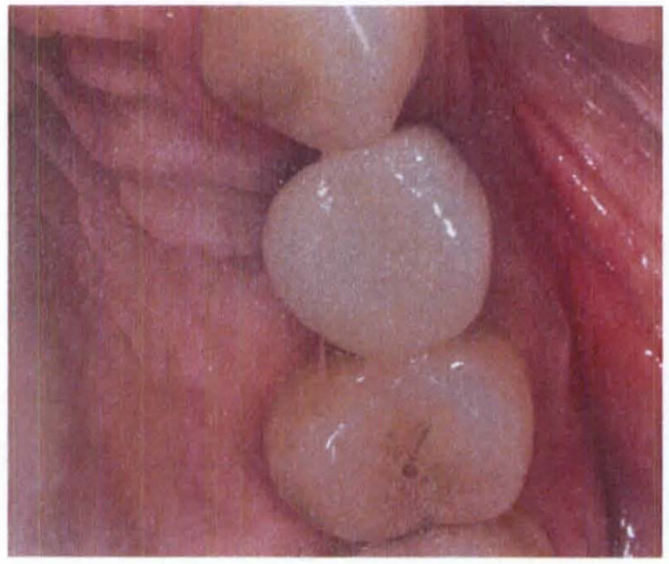




\section{REFERENCES}

Aalam A, Nowzari H. Clinical evaluation of dental implants with surfaces roughened by anodic oxidation, dual acid-etched implants, and machined implants. Int $\mathrm{J}$ Oral Maxillofac Implants 2005;20:793-798.

Albrektsson T, Zarb G, Worthington P, Eriksson AR. The long term efficacy of currently used dental implants: A review and proposed criteria of success. Int J Oral Maxillofac Implants 1986;1(1):11-25.

Allen EP. Minimally invasive surgery for soft tissue problems and implant sites. Forum Implantologicum 2011;7(2):86-92.

Andersson B, Odman P, Lindvall A, Lithner B. Single-tooth restorations supported by osseointegrated implants: Results and experiences from a prospective study after 2 to 3 years. Int J Oral Maxillofac Implants 1995;10:702-711.

Andersson B, Odman P, Widmark G, Waas A. Anterior tooth replacement with implants in patients with a narrow alveolar ridge form. A clinical study using guided tissue regeneration. Clin Oral Implants Res 1993;4(2):90-98.

Avivi-Arber L, Zarb GA. Clinical effectiveness of implant-supported single-tooth replacement: the Toronto study. Int J Oral Maxillofac Implants 1996;11:311-321.

Becker W, Ochsenbein C, Tibbetts L, Becker BE. Alveolar bone anatomic profiles as measured from dry skulls. Clinical ramifications. J Clin Periodontol 1997;24(10):727731.

Belser UC, Grutter L, Vailati F, Bornstein MM, Weber HP, Buser D. Outcome evaluation of early placed maxillary anterior single-tooth implants using objective esthetic criteria: A cross-sectional, retrospective study in 45 patients with a 2- to 4-year follow-up using pink and white esthetic scores. J Periodontol 2009;80(1):140-151.

Belser UC, Schmid B, Higginbottom F, Buser D. Outcome analysis of implant restorations located in the anterior maxilla: A review of the recent literature. Int J Oral Maxillofac Implants 2004;19 Suppl:30-42. 
Bengazi F, Wennstrom JL, Lekholm U. Recession of the soft tissue margin at oral implants. A 2-year longitudinal prospective study. Clin Oral Implants Res 1996;7:303310.

Botos S, Yousef H, Zweig B, Flinton R, Weiner S. The effects of laser microtexturing of the dental implant collar on crestal bone levels and peri-implant health. Int $\mathrm{J}$ Oral Maxillofac Implants 2011;26(3):492-498.

Brunette DM, Chehroudi. The effects of the surface topography of micromachined titanium substrata on cell behavior in vitro and in vivo. J Biomech Eng 1999;121(1): 4957.

Buser D, Bornstein MM, Weber HP, Grutter L, Schmid G, Belser UC. Early implant placement with simultaneous guided bone regneration following single-tooth extraction in the esthetic zone: a cross-sectional, retrospective study in 45 subjects with a 2- to 4 year follow-up. J Periodontol 2008;79:1773-1781.

Buser D, Martin W, Belser UC Optimizing esthetics for implant restorations in the anterior maxilla: anatomic and surgical considerations. Int J Oral Maxillofac Implants 2004;19 Suppl:43-61.

Buser D, Mericske-Stern R, Bernard JP, Behneke A, Behneke N, Hirt HP, Belser UC, Lang NP. Long-term evaluation of non-submerged ITI implants. Part 1: 8-year life table analysis of a prospective multi-center study with 2359 implants. Clin Oral Implants Res 1997;8:161-172.

Buser D, Wittneben J, Bornstein MM, Grutter L, Chappuis V, Belser UC. Stability of contour augmentation and esthetic outcomes of implant-supported single crowns in the esthetic zone: 3-year results of a prospective study with early implant placement postextraction. J Periodontol 2011;82(3):342-349.

Callan DP, Silverstein LH. Use of acellular dermal matrix for increasing keratinized tissue around teeth and implants. Pract Periodontics Aesthet Dent 1998;10(6):731-734

Canullo L, Fedele GR, Iannello G, Jepson S. Platform switching and marginal bone-level alterations: the results of a randomized-controlled trial. Clin Oral Implants Res 2010;21(1):115-121.

Canullo L, Rasperini G. Preservation of peri-implant soft and hard tissues using platform switching of implants placed in immediate extraction sockets: a proof-of-concept study with 12- to 36-month follow-up. Int J Oral Maxillofac Implants 2007;22:995-1000.

Cappiello M, Luongo R, Di Iorio D, Bugea, Cocchetto R, Celletti R. Evaluation of periimplant bone loss around platform-switched implants. Int J Periodontics Restorative Dent 2008;28:347-355. 
Cardaropoli G, Lekholm U, Wennstrom JL. Tissue alterations at implant-supported single-tooth replacements: a 1-year prospective clinical study. Clin Oral Implants Res 2006;17:165-171.

Castellon P, Casadaban M, Block MS. Techniques to facilitate provisionalization of implant restorations. J Oral Maxillofac Surg 2005;63(9):72-79.

Chang M, Wennstrom JL, Odman P, Andersson B. Implant supported single-tooth replacements compared to contralateral natural teeth. Crown and soft tissue dimensions. Clin Oral Implants Res 1999;10:185-194.

Choquet V, Hermans M, Adriaenssens P, Daelemans P, Tarnow DP, Malevez C. Clinical and radiographic evaluation of the papilla level adjacent to single-tooth dental implants. A retrospective study in the maxillary anterior region. J Periodontol 2001;72:1364-1371.

Chow YC, Wang HL. Factors and techniques influencing peri-implant papillae. Implant Dent 2010;19(3):208-219.

Chung S, Rungcharassaeng K, Kan JY, Roe P, Lozada JL. Immediate single tooth replacement with subepithelial connective tissue graft using platform switching implants: a case series. J Oral Implantol 2011;37(5):559-569.

Cochran DL, Hermann JS, Schenck R, Higginbottom F, Buser D. Biologic width around titanium implants. A histometric analysis of the implanto-gingival junction around unloaded and loaded nonsubmerged implants in the canine mandible. J Periodontol 1997;68:186-198.

Cooper LF, Ellner S, Moriarty J, Felton DA, Paquette D, Molina A, Chaffee N, Asplund P, Smith R, Hostner C. Three-year evaluation of single-tooth implants restored 3 weeks after 1-stage surgery. Int J Oral Maxillofac Implants 2007;22:791-800.

Cosyn J, Eghbali A, De Bruyn H, Collys K, Cleymaet R, De Rouck T. Immediate singletooth implants in the anterior maxilla: 3-year results of a case series on hard and soft tissue response and aesthetics. J Clin Periodontol 2011;38(8):746-753.

Davarpanah M, Martinez H, Etienne D, Zabalegui I, Mattout P, Chiche F, Michel JF. A prospective multicenter evaluation of 1,583 3i implants: 1- to 5-year data. Int $\mathbf{J}$ Oral Maxillofac Implants 2002;17:820-828.

David R. Provisional resoration for an osseointegrated single maxillary anterior implant. J Can Dent Assoc 2008;74(7):609-612.

De Bruyn $\mathrm{H}$, Atashkadeh $\mathrm{M}$, Cosyn $\mathrm{J}$, van de Velde T. Clinical outcome and bone preservation of single tiunite implants installed with flapless or flap surgery. Clin Implant Dent Relat Res 2011;13(3):175-183. 
De Rouck T, Collys K, Wyn I, Cosyn J. Instant provisionalization of immediate singletooth implants is essential to optimize esthetic treatment outcomes. Clin Oral Implants Res 2009;20:566-570.

Degidi M, Nardi D, Piattelli A. Peri-implant tissue and radiographic bone levels in the immediately restored single-tooth implant: A retrospective analysis. J Periodontol 2008a;79:252-259.

Degidi M, Novaes AB, Nardi D, Piattelli A. Outcome analysis of immediately placed, immediately restored implants in the esthetic area: The clinical relevance of different interimplant distances. J Periodontol 2008b;79:1056-1061.

Degidi M, Piattelli A, Gehrke P, Carinci F. Clinical outcome of 802 immediately loaded 2-stage submerged implants with a new grit-blasted and acid-etched surface: 12 month follow-up. Int J Oral Maxillofac Implants 2006;21:763-768.

Ekfeldt A, Carlsson GE, Borjesson G. Clinical evaluation of single-tooth restorations supported by osseointegrated implants: A retrospective study. Int J Oral Maxillofac Implants 1994;9:179-183.

Engquist B, Nilson H, Astrand P. Single-tooth replacement by osseointegrated Branemark implants. A retrospective study of 82 implants. Clin Oral Implants Res 1995;6(4):238-245.

Evans CD, Chen ST. Esthetic outcomes of immediate implant placements. Clin Oral Implants Res 2008;19:73-80.

Furhauser R, Florescu D, Benesch T, Haas R, Mailath G, Watzek G. Evaluation of soft tissue around single tooth implant crowns: The pink esthetic score. Clin Oral Implants Res 2005;16(6):639-644.

Gallucci GO, Grutter L, Chuang SK, Belser UC. Dimensional changes of peri-implant soft tissue over 2 years with single-implant crowns in the anterior maxilla. J Clin Periodontol 2011;26(1):293-299.

Gargiulo AW, Wentz FM, Oraban B. Dimensions and relations of the dentogingival junction in humans. J Periodontol 1961;32(3):261-267.

Gastaldo JF, Cury PR, Sendyk WR. Effect of the vertical and horizontal distances between adjacent implants and between a tooth and an implant on the incidence of interproximal papilla. J Periodontol 2004;75:1242-1246.

Giannopoulou C, Bernard J, Buser D, Carrel A, Belser UC. Effect of intracrevicular restoration margins on peri-implant health: Clinical, biochemical, and microbiologic findings around esthetic implants up to 9 years. Int $\mathrm{J}$ Oral Maxillofac Implants 2003;18:173-181. 
Gomez-Roman G. Influence of flap design on peri-implant interproximal crestal bone loss around single-tooth implants. Int J Oral Maxillofac Implants 2001;16:61-67.

Goodacre CJ, Bernal G, Rungcharassaeng K, Kan JY. Clinical complications with implants and implant prostheses. J Prosthet Dent 2003;90(2):70-71.

Goodacre CJ, Kan JY, Rungcharassaeng K. Clinical complications of osseointegrated implants J Prosthet Dent 1999;8(5):537-552.

Gotfredsen K. A 5-year prospective study of single-tooth replacements supported by the Astra Tech $\neg \notin$ implant: A pilot study. Clin Implant Dent Relat Res 2004;6(1):1-8.

Grunder U, Gracis S, Capelli M. Influence of the 3-D bone-to-implant relationship on esthetics. Int J Periodontics Restorative Dent 2005;25:113-119.

Grunder U, Polizzi G, Goene R, Hatano N, henry P, jackson WJ, Kawamura K, Kohler S, Renouard F. Rosenberg R, Triplett G, Werbitt M, Lithner B. A 3-year prospective multicenter follow-up report on the immediate and delayed-immediate placement of implants. Int J Oral Maxillofac Implants 1999;14:210-216.

Grunder U. Stability of the mucosal topography around single-tooth implants and adjacent teeth: 1-year results. Int J Periodontics Restorative Dent 2000;20:11-17.

Grutter L, Belser UC. Implant loading protocols for the partially edentulous esthetic zone. Int J Oral Maxillofac Implants 2009;24 Suppl:169-179.

Haas R, Polak C, Furhauser R, Mailath-Pokorny G, Dortbudak O, Watzek G. A longterm follow-up of 76 Branemark single-tooth implants. Clin Oral Implants Res 2002;13:38-43.

Hall JA, Payne AG, Purton DG, Torr B, Duncan WJ, De Silva RK. Immediately restored, single-tapered implants in the anterior maxilla: Prosthodontic and aesthetic outcomes after 1 year. Clin Implant Dent Relat Res 2007;9(1):34-45.

Henry PJ, Laney WR, Jemt T, Harris D, Krogh PH, Polizzi G, Zarb GA, Herrmann I. Osseointegrated implants for single-tooth replacement: A prospective 5-year multicenter study. Int J Oral Maxillofac Implants 1996;11(4):450-455.

Hermann JS, Buser D, Schenk RK, Schoolfield JD, Cochran DL. Biologic width around one- and two-piece titanium implants. A histometric evaluation of unloaded nonsubmerged and submerged implants in the canine mandible. Clin Oral Implants Res 2001;12:559-571. 
Hermann JS, Cochran DL, Nummikoski PV, Buser D. Crestal bone changes around titanium implants. A radiographic evaluation of unloaded nonsubmerged and submerged implants in the canine mandible. J Periodontol 1997;68:1117-1130.

Jemt T, Ahlberg G, Henriksson K, Bondevik O. Changes of anterior clinical crown height in patients provided with single-implant restorations after more than 15 years of followup. Int J Prosthodont 2006;19(5):455-461.

Jemt T, Laney WR, Harris D, Henry PJ, Krogh PH, Polizzi G, Zarb GA, Herrmann I. Osseointegrated implants for single tooth replacement: A 1-year report from a multicenter prospective study. Int J Oral Maxillofac Implants 1991;6:29-36.

Jemt T, Pettersson P. A 3-year follow-up study on single implant treatment. J Dent 1993;21(4):203-208.

Jemt T. Regeneration of gingival papillae after single-implant treatment. Int $\mathbf{J}$ Periodontics Restorative Dent 1997;17:327-333.

Jemt $\mathrm{T}$. Restoring the gingival contour by means of provisional resin crowns after singleimplant treatment. Int J Periodontics Restorative Dent 1999;19:21-29.

Kan JY, Rungcharassaeng K, Liddelow G, Henry P, Goodacre CJ. Periimplant tissue response following immediate provisional restoration of scalloped implants in the esthetic zone: A one-year pilot prospective multicenter study. J Prosthet Dent 2007;97:S109S118.

Kan JY, Rungcharassaeng K, Lozada J. Immediate placement and provisionalization of maxillary anterior single implants: 1-year prospective study. Int J Oral Maxillofac Implants 2003a;18:31-39.

Kan JY, Rungcharassaeng K, Lozada JL, Zimmerman G. Facial gingival tissue stability following immediate placement and provisionalization of maxillary anterior single implants: A 2- to 8-year follow-up. Int J Oral Maxillofac Implants 2011;26(1):179-187.

Kan JY, Rungcharassaeng K, Morimoto T. Facial gingival tissue stability after connective tissue graft with single immediate tooth replacement in the esthetic zone: Consecutive case report. J Oral Maxillofac Surg 2009;76:40-48.

Kan JY, Rungcharassaeng K, Umezu K, Kois JC. Dimensions of peri-implant mucosa: An evaluation of maxillary anterior single implants in humans. $J$ Periodontol 2003b;74:557-562.

Karlsson U, Gotfredsen K, Olsson C. Single-tooth replacement by osseointegrated Astra Tech dental implants: A 2 year report. Int J Prosthodont 1997;10(4):318-324. 
Kawai ES, Almeida AL. Evaluation of the presence or abscence of papilla between tooth and implant. Cleft Palate Craniofac J 2008;45(4):399-406.

Kemppainen P, Eskola S, Ylipaavalniemi P. A comparative prospective clinical study of two singl-tooth implants: A preliminary report of 102 implants. J Prosthet Dent 1997;77:382-387.

Khayat PG, Milliez SN. Prospective clinical evaluation of 835 multithreaded tapered screw-vent implants: Results after two years of functional loading. J Oral Implantol 2007;33(4):225-231.

Kim B, Kim Y, Yun P, Yi Y, Lee H, Kim S, Son J. Oral Surg Oral Med Oral Pathol Oral Radiol Endod 200910724-28

Kois JC, Kan JY. Predictable peri-implant gingival aesthetic: Surgical and prosthodontic rationales. Pract Proced Aesthet Dent 2001b;13(9):691-698.

Kois JC. Altering gingival levels: The restorative connection. Part I: Biologic variables.Article J Esthet Dent 1994;6(1):3-9.

Kois JC. Predictable single tooth peri-implant esthetics: Five diagnostic keys. Compend Contin Educ Dent 2001a;22(3):199-206.

Laney WR, Jemt T, Harris D, Henry PJ, Krogh PH, Polizzi G, Zarb GA, Herrmann I. Osseointegrated implants for single-tooth replacement: Progress report from a multicenter prospective study after 3 years. Int J Oral Maxillofac Implants 1994;9(1):4954.

Laster L, Laudenbach K, Stoller N. An evaluation of clinicial mobility measurements. J Periodontol 1975;46(10);603-607.

Lazzara RJ. Porter SS. Platform switching: A new concept in implant dentistry for controlling postrestorative crestal bone levels. Int $\mathrm{J}$ Periodontics Restorative Dent 2006;26(1):9-17.

Lee D, Park K, Moon I. Dimensions of interproximal soft tissue between adjacent implants in two distinctive implant systems. J Periodontol 2006;77:1080-1084.

Lee Y. Peri-implant soft tissue level secondary to a connective tissue graft in conjunction with immediate implant placement: a 2-year follow-up report of 11 consecutive cases. Int J Periodontics Restorative Dent 201232(2)213-222

Lekholm U, Zarb G, Albrektsson T. Tissue integrated prosthesis: Osseointegration in clinical dentistry. Quintessence Int 1985;199-205. 
Levin L, Pathael S, Dolev E, Schwartz-Arad D. Aesthetic versus surgical success of single dental implants: 1- to 9-year follow-up. Pract Proced Aesthet Dent 2005;17(8):533-538.

Levine RA, Clem DS, Wilson T, Higginbottom F, Solnit G. Multicenter retrospective analysis of the ITI implant system used for single-tooth replacements: Results of loading for 2 or more years. Int J Oral Maxillofac Implants 1999;14:516-520.

Levine RA, Clem DS, Wilson TG, Higginbottom F, Saunders SL. A multicenter retrospective analysis of the ITI implant system used for single-tooth replacements: Preliminary results at 6 or more months of loading. Int $\mathbf{J}$ Oral Maxillofac Implants 1997;12:237-242.

Leziy S. Replacement of adjacent missing anterior teeth with scalloped implants: a case report. Pract Proced Aesthet Dent 2005;17(5):331-338.

Lobene R, Weatherford T, Ross W. A modified gingival indices for use in clinical trials. Clin Prev Dent 1986;8(1):3-6.

London RM. The esthetic effects of implant platform selection. Compend Contin Educ Dent 2001;22(8):675-682.

Lops D, Chiapasco M, Rossi A, Bressan E, Romeo E. Incidence of inter-proximal papilla between a tooth and an adjacent immediate implant placed into a fresh extraction socket: 1-year prospective study. Clin Oral Implants Res 2008;19:1135-1140.

Lops D, Mosca D, Muller A, Rossi A, Rozza R, Romeo E. Management of peri-implant soft tissues between tooth and adjacent immediate implant placed into fresh extraction single socket: A one-year prospective study on two different types of implant-abutment connection design. Minerva Stomatol 2011;60(9):403-415.

Melevez C, Hermans M, Daelemans P. Marginal bone levels at Branemark system implants used for single tooth restoration. The infuence of implant design and anatomical region. Clin Oral Implants Res 1996;7(2):162-169.

Moberg L, Kondell P, Kullman L, Heimdahl A, Gynther GW. Evaluation of single-tooth restorations on ITI dental implants. A prospective study of 29 patients. Clin Oral Implants Res 1999;10:45-53.

Morris HF, Ochi S. Influence of two different approaches to reporting implant survival outcomes for five different prosthodontic applications. Ann Periodontol 2000;5(1):129136.

Naert I, Koutsikakis G, Duyck J, Quiryen M, Jacobs R, van steenberghe D. Biologic outcome of implant-supported restorations in the treatment of partial edentulism. part 1: A longitudinal clinical evaluation. Clin Oral Implants Res 2002;13:381-389. 
Nemcovsky CE, Moses O, Artzi Z. Interproximal papillae reconstruction in maxillary implants. J Periodontol 2000;71:308-314.

Nevins M, Camelo M, Nevins ML, Schupbach P, Kim DM. Connective tissue attachment to laser-microgrooved abutments: A human histologic case report. Int $\mathrm{J}$ Periodontics Restorative Dent 2012;32(4):385-392.

Nevins M, Kim DM, Jun SH, Guze K, Schupbach P, Nevins ML. Histologic evidence of a connective tissue attachment to laser microgrooved abutments: A canine study. Int $J$ Periodontics Restorative Dent 2010;30(3):245-255.

Nevins M, Nevins ML, Camelo M, Boyesen JL, Kim DM. Human histologic evidence of a connective tissue attachment to a dental implant. Int $\mathbf{J}$ Periodontics Restorative Dent 2008;28(2):111-121.

Nisapakultorn K, Suphanantachat S, Silkosessak O, Rattanamongkolgul S. Factors affecting soft tissue level around anterior maxillary single-tooth implants. Clin Oral Implants Res 2010;21(6):662-670.

Norton MR. The Astra Tech single-tooth implant system: A report on 27 consecutively placed and restored implants. Int J Periodontics Restorative Dent 1997;17:575-583.

Oates TW, West J, Jones J, Kaiser D, Cochran DL. Long-term changes in soft tissue height on the facial surface of dental implants. Implant Dent 2002;11(3):272-276.

Ochsenbein C, Ross S. A reevaluation of osseous surgery. Dent Clin North Am 1969;13(1):87-102.

Olsson M, Lindhe J, Marinello CP. On the relationship between crown form and clinical features of the gingiva in adolescents. J Clin Periodontol 1993;20:570-577.

Olsson M, Lindhe J. Periodontal characteristics in individuals with varying form of the upper central incisors. J Clin Periodontol 1991;18:78-82.

Palattella P, Torsello F, Cordaro L Two-year prospective clinical comparison of immediate replacement vs. immediate restoration of single tooth in the esthetic zone. Clin Oral Implants Res 2008;19:1148-1153.

Palmer RM, Palmer PJ, Smith BJ. A 5-year prospective study of Astra single tooth implants. Clin Oral Implants Res 2000;11(2):179-182.

Palmer RM, Palmer PL, Newton T. Dealing with esthetic demands in the anterior maxilla. Periodontol 2000 2003;33:105-118. 
Palmer RM, Smith BJ, Palmer PJ, Floyd PD. A prospective study of Astra single tooth implants. Clin Oral Implants Res 1997;8:173-179.

Park JB. Healing of extraction socket grafted with deproteinized bovine bone and acellular dermal matrix: histomorphometric evaluation. Implant Dent 2010;19(4):307313.

Patel K, Marda N, Donos N. Radiographic and clinical outcomes of implants placed in ridge preserved sites: A 12-month post-loading follow-up. Clin Oral Implants Res 2012; epub:1-7.

Penarrocha-Oltra D, Demarchi CL, Maestre-Ferrin L, Penarrocha-Diago M, PenarrochaDiago M. Comparison of immediate and delayed implants in the maxillary molar region: A retrospective study of 123 implants. Int J Oral Maxillofac Implants 2012;27(3):604610.

Priest G. Single-tooth implants and their role in preserving remaining teeth: A 10-year survival study. Int J Oral Maxillofac Implants 1999;14:181-188.

Priest G. Predictability of soft tissue form around single-tooth implant restorations. Int $J$ Periodontics Restorative Dent 2003;23:19-27.

Raes F, Cosyn J, Crommelinck E, Coessens P, De Bruyn H. Immediate and conventional single implant treatment in the anterior maxilla: 1-year results of a case series on hard and soft tissue response and aesthetics. J Clin Periodontol 201 1;38(4):385-394.

Ribeiro FS, Pontes AE, Marcantonio E, Piattelli A, Neto RJ, Marcantonio E. Success rate of immediate nonfunctional loaded single-tooth implants: Immediate versus delayed implantation. Implant Dent 2008;17(1):109-117.

Romanos GE, Traini T, Johansson CB, Piattelli A. Biologic width and morphologic characteristics of soft tissues around immediately loaded implants: Studies performed on human autopsy specimens. J Periodontol 2010;81(1):70-78.

Romeo E, Chiapasco M, Ghisolfi M, Vogel G. Long-term clinical effectiveness of oral implants in the treatment of partial edentulism. Seven year life table analysis of a prospective study with ITI $\neg Æ$ Dental Implant system used for single-tooth restorations. Clin Oral Implants Res 2002;13:133-143.

Romeo E, Lops D, Rossi A, Storelli S, Rozza R, Chiapasco M. Surgical and prosthetic management of interproximal region with single-implant restorations: 1-year prospective study. J Periodontol 2008;79:1048-1055.

Roos J, Sennerby L, Lekholm U, Jemt T, Grondahl K, Albrektsson T. A qualitative and quantitative method for evaluating implant success: A 5-year retrospective analysis of the Branemark implant. Int J Oral Maxillofac Implants 1997;12:504-514. 
Rosenberg ES, Torosian J. An evaluation of differences and similarities observed in fixture failure of five distinct implant systems. Pract Periodontics Aesthet Dent $1998 ; 10(6): 687-698$.

Ryser MR, Block MS, Mercante DE. Correlation of papilla to crestal bone levels around single tooth implants in immediate or delayed crown protocols. J Oral Maxillofac Surg 2005;63:1184-1195.

Saadoun AP. The key to peri-implant esthetics: Hard- and soft-tissue management. Dent Update 1997;8(6):41-46.

Salama H, Salama MA, Garber D, Adar P. The interproximal height of bone: A guidepost to predictable aesthetic strategies and soft tissue contours in anterior tooth replacement. Pract Periodontics Aesthet Dent 1998;10(9): 1131-41.

Santosa RE. Provisional restoration options in implant dentistry. Aust Dent J 2007;52(3):234-242.

Scheller H, Urgell JP, Kultje C, Klineberg I, Goldberg PV, Stevenson-Moore P, Alonso JM, Schaller M, Corria RM, Engquist B, Toreskog S, Kastenbaum F, Smith CR. A 5-year multicenter study on implant-supported single crown restorations. Int J Oral Maxillofac Implants 1998;13:212-218

Schmitt A, Zarb GA. The longitudinal clinical effectiveness of osseointegrated dental implants for single-tooth replacement. Int J Prosthodont 1993;6:197-202.

Scholander S. A retrospective evaluation of 259 single-tooth replacements by the use of Branemark implants. Int J Prosthodont 1999;12:483-491.

Schropp L, Isidor F, Kostopoulos L, Wenzel A. Interproximal papilla levels following early versus delayed placement of single-tooth implants: A controlled clinical trial. Int $\mathrm{J}$ Oral Maxillofac Implants 2005;20:753-761.

Schropp L, Isidor F. Clinical outcome and patient satisfaction following full-flap elevation for early and delayed placement of single-tooth implants: A 5-year randomized study. Int J Oral Maxillofac Implants 2008;23:733-743.

Seibert J, Lindhe J. Esthetics in periodontal therapy. In Clinical Periodontology and Implant Dentistry, Lindhe J, Karring $\mathrm{T}$ and Lang NP, eds. Munksgaard: Copenhagen, 1997.

Silness $\mathbf{J}$, Loe H. Periodontal disease in pregnancy. II. Correlation between oral hygiene and periodontal condition. Acta Odontol Scand 1964;22(1):121-135. 
Small PN, Tarnow DP, Cho SC. Gingival recession around wide-diamter versus standarddiameter implants: A 3 to 5 year longitudinal prospective study. Pract Proced Aesthet Dent 2001;13(2):143-146.

Small PN, Tarnow DP. Gingival recession around implants: A 1-year longitudinal prospective study. Int J Oral Maxillofac Implants 2000;15:527-532.

Smith DE, Zarb GA. Criteria for success of osseointegrated endosseous implants. J Prosthet Dent 1989;62(5):567-572.

Spray JR, Black CG, Morris HF, Ochi S. The influence of bone thickness on facial marginal bone response: Stage 1 placement through stage 2 uncovering. Ann Periodontol 2000;5(1):119-128.

Tarnow DP, Cho SC, Wallace SS. The effect of inter-implant distance on the height of inter-implant bone crest. J Periodontol 2000;71:546-549.

Tarnow DP, Elian N, Fletcher P, Froum S, Magner A, Cho SC, Salama M, Salama H, Garber DA. Vertical distance from the crest of bone to the height of the interproximal papilla between adjacent implants. J Periodontol 2003;74:1785-1788.

Tarnow DP, Eskow RN. Preservation of implant esthetics: Soft tissue and restorative considerations. J Esthet Dent 1996;8(1):12-19.

Tarnow DP, Magner AW, Fletcher P. The effect of the distance from the contact point to the crest of bone on the presence or absence of the interproximal papilla. J Periodontol 1992;63:995-996.

Thilander B Odmann J, Jemt T. Single implants in the upper incisor region and their relationship to the adjacent teeth. Clin Oral Implants Res 1999;10:346-355.

Tortamano P, Carmago LO, Bello-Silvo MS, Kanashiro LH Immediate implant placement and restoration in the esthetic zone: a prospective study with 18 months of follow-up. Int J Oral Maxillofac Implants 2010;25(2):345-350.

Valentini P, Abensur D, Albertini JF, Rocchesani M. Immediate provisionalization of single extraction-site implants in the esthetic zone: a clinical evaluation. Int $\mathbf{J}$ Periodontics Restorative Dent 2010;30(1):41-51.

van Steenberghe D, De Mars G, Quirynen M, Jacobs R, Naert I. A prospective splitmouth comparative study of two screw-shaped self-tapping pure titanium implant systems. Clin Oral Implants Res 2000;11:202-209.

Walther W, Klemke J, Worle $\mathbf{M}$, Heners $\mathbf{M}$. Implant-supported single-tooth replacements: Risk of implant and prosthesis failure. J Oral Implantol 1996;22(3-4):236239. 
Weber HP, Kim DM, Ng MW, Hwang JW, Fiorellini JP. Peri-implant soft tissue health surrounding cement- and screw-retained implant restorations: A multi-center, 3-year prospective study. Clin Oral Implants Res 2006;17:375-379.

Weiner S, Simon J, Ehrenberg DS, Zxeig B, Ricci JL. The effects of laser microtextured collars upon crestal bone levels of dental implants Implant Dent 2008;17:217-228.

Wheeler R. Wheeler R (ed. 5) Dental Anatomy Physiology, and Occlusion. Philadelphia, W. B. Sanders Company, 1974. Book 1974;124-126.

Wheeler SL. Eight-year clinical retrospective study of titanium plasma-sprayed and hydroxyapatite-coated cylinder implants. Int J Oral Maxillofac Implants 1996;11:340350 .

Wiesner G, Esposito M, Worthington H, Schlee M. Connective tissue grafts for thickening peri-implant tissues at implant placement. one-year results from an explanatory split-mouth randomized controlled clinical trial. Int $\mathbf{J}$ Oral Implantol 2010;3(1):27-35.

Wyatt CC, Zarb GA. Treatment outcomes of patients with implant-supported fixed partial prostheses. Int J Oral Maxillofac Implants 1998;13:204-211.

Yan JJ, Tsai AY, Wong MY, Hou LT. Comparison of acellular dermal graft and palatal autograft in the reconstruction of keratinized gingiva around dental implants: A case report. Int J Periodontics Restorative Dent 2006;26(3):287-292.

Zigdon $\mathrm{H}$, Machtei EE. The dimensions of keratinized mucosa around implants affect clinical and immunological parameters. Clin Oral Implants Res 2008;19:387-392.

Zitzmann NU, Scharer P, Marinello CP. Long-term results of implants treated with guided bone regeneration: A 5 year prospective study. Int J Oral Maxillofac Implants 2001;16:355-366. 


\section{$\underline{\text { Appendix A }}$}

\section{The Plaque Index}

Silness J, Löe H. Periodontal disease in pregnancy. II. Correlation between oral hygiene and periodontal condition. Acta Odontol Scand 1964;22(1):121-135.

The plaque index of Silness and Loe (1964) will be measured. Scores will be as follows:

0 - No plaque

1 - A film of plaque adhering to the free gingival margin and adjacent area of the tooth. The plaque may be seen in situ only after application of disclosing solution or by using the probe on the tooth surface.

2 - Moderate accumulation of soft deposits within the gingival pocket, or on the tooth and gingival margin which can be seen with the naked eye.

3 - Abundance of soft matter within the gingival pocket and/or on the tooth and gingival margin.

Each gingival unit (buccal, lingual, mesiobuccal, distobuccal, mesiolingual, and distolingual) of the individual tooth will be given a score from $0-3$, called the plaque index for the area. The scores from the 6 areas of the tooth are added and divided by 6 to give the plaque index for the tooth. 


\section{$\underline{\text { Appendix B }}$}

\section{The Gingival Index}

Lobene R, Weatherford T, Ross W. A modified gingival indices for use in clinical trials. Clin Prev Dent 1986;8(1):3-6.

The Gingival Index (Lobene et al. 1986) will be measured. Scores will be as follows:

0 - Normal gingiva

1 - Mild inflammation - slight change in color, slight edema

2 - Moderate inflammation - redness, edema, and glazing.

3 - Severe inflammation - marked redness and edema. Ulceration.

Each gingival unit (buccal, lingual, mesiobuccal, distobuccal, mesiolingual, and distolingual) of the individual tooth will be given a score from $0-3$, called the gingival index for the area. The scores from the 6 areas of the tooth are added and divided by 6 to give the gingival index for the tooth. 


\section{$\underline{\text { Appendix C }}$}

\section{Tooth Mobility}

Laster L, Laudenbach K, Stoller N. An evaluation of clinical mobility measurements. J Periodontol 1975;46(10):603-607.

Miller proposed the following tooth mobility index:

0 - Movability of the crown within normal physiologic limits.

1 - Movability of the crown up to $0.5 \mathrm{~mm}$ in one direction. Does not exceed $1.0 \mathrm{~mm}$ in both directions.

2 - Movability of the crown from 0.5 to $1 \mathrm{~mm}$ in one direction. Does not exceed $2.0 \mathrm{~mm}$ in both directions.

3 - Movability of the crown exceeding $1 \mathrm{~mm}$ in one direction and/or vertical depressibility. Greater than $2.0 \mathrm{~mm}$ in both directions and/or vertical depressibility.

The index that will be used in the study is a modification of Miller's index (Laster et al., 1975) where half scores are used. Thus scores of $0,0.5,1,1.5,2,2.5$, and 3 will be utilized. 


\section{Appendix D}

\section{Standardized Radiographic Technique}

An occlusal stent is used to provide a stable foundation for the radiograph holder. The stent is placed on a cast and the Rinn radiograph holder is positioned to allow as near as possible paralleling technique. They are constructed using Regisil ${ }^{\circledR} \mathrm{PB}^{\mathrm{TM}}$ Plaster Bite Registration Paster and a Rinn-XCP on the patient model. Radiographs will be taken at baseline, pre-implant placement, immediately post-implant placement, 2 months, 4 months and 6 months post-implant placement. 


\section{$\underline{\text { Appendix E }}$}

\section{Periodontal Form}

Kois JC: Altering gingival levels: the restorative connection part I: biologic variables. J Esthet Dent 1994;6(1):3-9.

Kois found the following average measurements for categories of periodontal form:

High: A distance of greater than $5 \mathrm{~mm}$ exists from the midfacial free gingival margin to a periodontal probe positioned horizontally at the most coronal tip of the interproximal papilla.

Normal: A distance of 4 to $5 \mathrm{~mm}$ exists from the midfacial free gingival margin to a periodontal probe positioned horizontally at the most coronal tip of the interproximal papilla.

Flat: A distance of less than $4 \mathrm{~mm}$ exists from the midfacial free gingival margin to a periodontal probe positioned horizontally at the most coronal tip of the interproximal papilla.

Pronounced scalloped, scalloped, and flat will be substituted for High, normal, and flat, respectively in the study. 


\section{Appendix F}

\section{Periodontal Biotype}

A UNC periodontal probe will be inserted into the gingival sulcus of the facial tooth surface. If the probe is not visible through the facial gingival, a thick biotype will be assigned. If only the black color of the probe markings are visible, a moderate biotype will be assigned. If the millimeter markings on the probe are completely visible through the tissues the biotype will be designated as thin. 


\section{Appendix G}

\section{Papilla Harmony}

A line will be extrapolated that is perpendicular to the midline of the maxillary arch. If corresponding papilla tips are located at the same point with reference to this line, papillae will be considered harmonious. If the papillae are not located at the same point, papillae will not be considered harmonious, and the discrepancy will be measured. 


\section{Appendix H}

\section{Gingival Margin Harmony}

If the gingival margin is even with adjacent teeth, it will be considered harmonious. If the gingival margin is not even adjacent teeth, it will not be considered harmonious, and the discrepancy will be measured. 


\section{Appendix I}

\section{Subjective Evaluation of Implant Placement}

Buccal-lingual placement: Buccal, Optimal, or Lingual.

Incisal-apical placement: Incisal, Optimal, or Apical.

Mesial-distal placement: Mesial, Optimal, or Distal. 


\section{$\underline{\text { Appendix J }}$}

\section{Bone Quality}

Lekholm U, Zarb G, Albrektsson T. Tissue integrated prosthesis: Osseointegration in clinical dentistry. Quintessence1985;199-205.

1. Almost the entire jaw is comprised of homogeneous compact bone.

2. A thick layer of compact bone surrounds a core of dense trabecular bone.

3. A thin layer of cortical bone surrounds a core of dense trabecular bone of favorable strength.

4. A thin layer of cortical bone surrounds a core of low density trabecular bone. 


\section{Appendix K}

\section{Pink Esthetic Score}

Furhauser R, Flourescu D, Benesch T, Haas R, Mailath G. Evaluation of soft tissue around single-tooth implant crowns: The pink esthetic score. Clin Oral Implants Res 2005;16(6):639-644.

Seven variables are assessed with a score of 2,1 , or 0 with 2 being the best and 0 being the worst with the highest possible score attainable being 14 (score of $2 \times 7$ variables).

\begin{tabular}{|l|l|l|l|}
\hline Variables & $\mathbf{0}$ & $\mathbf{1}$ & $\mathbf{2}$ \\
\hline Mesial Papilla & Absent & Incomplete & Present \\
\hline Distal Papilla & Absent & Incomplete & Present \\
\hline $\begin{array}{l}\text { Level of Soft } \\
\text { Tissue Margin }\end{array}$ & $\begin{array}{l}\text { Major } \\
\text { Discrepancy }> \\
\text { 2mm }\end{array}$ & $\begin{array}{l}\text { Minor } \\
\text { Discrepancy 1-2 } \\
\text { mm }\end{array}$ & $\begin{array}{l}\text { No } \\
\text { Discrepancy }< \\
\text { 1mm }\end{array}$ \\
\hline $\begin{array}{l}\text { Soft-Tissue } \\
\text { Contour }\end{array}$ & Unnatural & Fairly Natural & Natural \\
\hline Alveolar Process & Obvious & Slight & None \\
\hline $\begin{array}{l}\text { Soft-Tissue } \\
\text { Color }\end{array}$ & $\begin{array}{l}\text { Obvious } \\
\text { Difference }\end{array}$ & $\begin{array}{l}\text { Moderate } \\
\text { Difference }\end{array}$ & No Difference \\
\hline $\begin{array}{l}\text { Soft-Tissue } \\
\text { Texture }\end{array}$ & $\begin{array}{l}\text { Obvious } \\
\text { Difference }\end{array}$ & $\begin{array}{l}\text { Moderate } \\
\text { Difference }\end{array}$ & No Difference \\
\hline
\end{tabular}




\section{$\underline{\text { Appendix L }}$}

\section{White Esthetic Score}

Belser UC, Grutter L, Vailati F, Bornstein MM, Weber HP, Buser D. Outcome evaluation of early placed maxillary anterior single-tooth implants using objective esthetic criteria: A cross-sectional, retrospective study in 45 patients with a 2- to 4-year follow-up using pink and white esthetic scores. J Periodontol 2009; 80(1):140-151.

Five variables are assessed with a score of 2,1 , or 0 with 2 being the best and 0 being the worst with the highest possible score attainable being 10 (score of $2 \times 5$ variables).

\begin{tabular}{|c|c|c|c|}
\hline Variables & 0 & 1 & 2 \\
\hline Tooth form & $\begin{array}{l}\text { Major } \\
\text { Discrepancy }\end{array}$ & $\begin{array}{l}\text { Minor } \\
\text { Discrepancy }\end{array}$ & $\begin{array}{l}\text { No } \\
\text { Discrepancy }\end{array}$ \\
\hline $\begin{array}{l}\text { Tooth } \\
\text { volume/outline }\end{array}$ & $\begin{array}{l}\text { Major } \\
\text { Discrepancy }\end{array}$ & $\begin{array}{l}\text { Minor } \\
\text { Discrepancy }\end{array}$ & $\begin{array}{l}\text { No } \\
\text { Discrepancy }\end{array}$ \\
\hline $\begin{array}{l}\text { Color } \\
\text { (hue/value) }\end{array}$ & $\begin{array}{l}\text { Major } \\
\text { Discrepancy }\end{array}$ & $\begin{array}{l}\text { Minor } \\
\text { Discrepancy }\end{array}$ & $\begin{array}{l}\text { No } \\
\text { Discrepancy }\end{array}$ \\
\hline Surface texture & $\begin{array}{l}\text { Major } \\
\text { Discrepancy }\end{array}$ & $\begin{array}{l}\text { Minor } \\
\text { Discrepancy }\end{array}$ & $\begin{array}{l}\text { No } \\
\text { Discrepancy }\end{array}$ \\
\hline Translucency & $\begin{array}{l}\text { Major } \\
\text { Discrepancy }\end{array}$ & $\begin{array}{l}\text { Minor } \\
\text { Discrepancy }\end{array}$ & $\begin{array}{l}\text { No } \\
\text { Discrepancy }\end{array}$ \\
\hline
\end{tabular}




\section{Appendix M}

\section{Jemt Papilla Index Scoring System}

Jemt T. Regeneration of gingival papillae after single-implant treatment. Int J

Periodontics Restorative Dent 1997;17(4):326-333.

The mesial and distal papillae were each given a score of 0 to 4 .

\begin{tabular}{|l|l|}
\hline Score 0 & No papilla is present. \\
\hline Score 1 & Less than half the papilla is present \\
\hline Score 2 & $\begin{array}{l}\text { At least half of the papilla is present but the papilla tip does not extend to the interproximal } \\
\text { contact point. }\end{array}$ \\
\hline Score 3 & Papilla completely fills the embrasure space and is harmonious with the adjacent papilla. \\
\hline Score 4 & The papilla is overfilling the embrasure and covering the adjacent crown. \\
\hline
\end{tabular}




\section{$\underline{\text { Appendix N }}$}

1. I am pleased with the appearance of my implant tooth compared to the surrounding teeth.

0 100

2. I am pleased with the appearance of the gums around my implant tooth.

0 100

3. Overall, I am pleased with the appearance of my implant tooth.

0 100 


\section{$\underline{\text { Appendix } 0}$}

Examiner calibration: Probing measurements only.

The data will be compared from indices or measurements taken by the examiner on three different patients at two different times within a 60 minute period to measure the inter examiner accuracy and reproducibility.

1. A minimum of three subjects are to be recruited to participate in the calibration. The subjects should exhibit a range of the criteria being assessed in the index or measurements being performed (i.e., subjects with moderate to severe periodontal disease).

2. The examiner will score 6 teeth per subject within the same quadrant.

3. The examiner will measure each subject, calling out the measurements, site by site, while the assistant records. The subjects will not eat or brush their teeth between scorings.

4. Duplicate measurements of the subjects will be taken within 60 minutes following the initial measurements. The assistant will record the second set of data.

5. The examiner will not compare the two sets of data at any time during the calibration. The examiner will not discuss their measurements with the assistant or the subject during the calibration.

6. The assistant recording the data will be responsible for handling the data sheets. The examiner will have no access to any of the data sheets during the course of the calibration. 
8. The data sets will be analyzed for percent agreement. Acceptable percent agreement will reflect the limits set for the different parameters measured.

9. Acceptable percent agreement will be: $90 \% \mathrm{w} / \mathrm{in} \pm 1 \mathrm{~mm}$ for probing depth, recession and attachment level and $70 \%$ within $0 \mathrm{~mm}$. 


\title{
CURRICULUM VITAE
}

\author{
Gretchen A. Wigand
}

\section{Education:}

Periodontics Resident, University of Louisville School of Dentistry (ULSD), June 2009- Current

D.M.D., University of Louisville School of Dentistry (ULSD), May 2009

- Cumulative GPA: 3.624 (Ranked 8/77)

B.A., Biology, University of Louisville, August 1997 - May 2005

- Cumulative GPA: 3.539

\section{Professional Associations:}

- Academy of Osseointegration, 2010-present

- American Association of Periodontology, 2010-present

- Omicron Kappa Upsilon, National Dental Honor Society, 2009 - present

- American Dental Association, 2005 - present

- Multiple Sclerosis Society, 2003

- Louisville American Student Dental Association (LASDA)

- Senior Class Representative Louisville chapter, 2008

- Louisville Corporate Achievers Program, 2003

\section{Honors and Activities:}

- ULSD Dean's List, GPA of at least 3.30, 2005-2009

- ULSD Dean's Scholar, GPA of at least 3.80, Spring 2006, Fall 2007, Spring 2008, Fall 2008, Spring 2009

- ULSD Top 10\%, Anatomical Sciences, Spring 2006, Pharmacology, Spring 2007

- ULSD Tutor, Microbiology, Biochemistry, Physiology, Dental Anatomy, 2006-2009

- ULSD Pre-Clinical Student Teacher, Dental Anatomy, 2008- 2009

- Meyers Scholarship, 2006/2007 academic period

- Multiple Sclerosis Corporate Achiever, Louisville, KY, 2003

\section{Public Outreach:}

- The RAM Project in Pikeville, KY, June 2009

- Smile Kentucky Student Volunteer, Spring 2008, Spring 2009

- Colgate Kids Screening, Fall 2007

- Sealants for Kentucky's Children at Kentucky State Fair, Fall 2005, 2007 
- Oral Cancer Screening at Kentucky Sate Fair, Fall 2008

- Wayside Homeless Shelter Women's and Children's Oral Education Program, Fall 2006, 2007

- Center for Health Hazards Preparedness, Fall 2007

- National Multiple Sclerosis Foundation, 2003

\section{Work Experience:}

- AHEC 5-week general dentistry externship with Drs. Martin Segal \& Anna Perry at Advanced Dental Care of Louisville, KY, May - June 2008

- Completed two more weeks of AHEC externship than required as Senior DMD student at ULSD, June 2008

- Sole proprietor and manager of Bliss Image Consultants in Louisville, KY; Owned and operated upscale spa, provided services, supervised employees, maintained long-term client relationships, 1998 - 2005. 